\title{
Morcegos cavernícolas da região do Distrito Federal, centro-oeste do Brasil (Mammalia, Chiroptera)
}

\author{
Angelika Bredt ${ }^{1}$ \\ Wilson Uieda ${ }^{2}$ \\ Edvard Dias Magalhães ${ }^{3}$
}

\begin{abstract}
Cave bats from the Distrito Federal area in Mid-Western Brazil (Mammalia, Chiroptera). Between 1989 and 1995, twenty caves in the Distrito Federal area in mid-western Brazil were assessed for bat species richness, frequency, spatial distribution, behavior, reproduction and inter-specific cohabitation. The general state of conservation of the caves was also assessed. Of the 20 caves studied, 12 were less than $100 \mathrm{~m}$ long, five between $100 \mathrm{~m}$ and $300 \mathrm{~m}$, and three were longer than $300 \mathrm{~m}$. Twenty-two species of six different families were observed: 16 species belonged to Phyllostomidae, two to Vespertilionidae and Mormoopidae and one to Furipteridae and Emballonuridae. In this study, 17 species were characterized as Distrito Federal cave dwellers. The most prevalent were Desmodus rotundus, Glossophaga soricina and Carollia perspicillata. The least prevalent were Lonchorhina aurita, Pteronotus gymnonotus and Phylloderma stenops. Since some Anoura caudifer, Platyrrhinus lineatus, Myotis nigricans, Micronycteris minuta, and Eptesicus brasiliensis individuals were captured only while going into the caves early in the night, they were not considered cave dwellers. Even though, they probably use the caves as a daytime roosting place. Surprisingly, Lonchophylla dekeyseri, considered to be the only endemic bat species in the Cerrado ecosystem, was observed in three of the surveyed caves. Further biological studies are necessary to determine the biology of $L$. dekeyseri and the necessity of its conservation. The bat colonies observed were usually of a small size. Few colonies of D. rotundus and Anoura geoffroyi contained more than 300 individuals of both sexes. Only a male group of $L$. aurita was observed in the Distrito Federal area. Twelve of the surveyed caves were hard to access and therefore well protected. Four of the caves received some public visitation, two were located near limestone mines, one was located near an urban area, and one had both public visitation and deforestation near its entrance. In this latter cave, no bats were observed after november 1994, probably due to the urbanization process. Special attention should be given to eight of the surveyed caves in any plan made for the conservation of cave bats in the Distrito Federal area. These caves host a high bat diversity (six or more species) and also shelter two rare and one endemic bat species. KEY WORDS. Mammalia, ecology, behavior, cave bats communities, conservation, neotropical region
\end{abstract}

1) Gerência de Controle de Zoonoses, Instituto de Saúde do Distrito Federal. 70620-000 Brasília, Distrito Federal, Brasil.

2) Departamento de Zoologia, Instituto de Biociências, Universidade Estadual Paulista. 18618-000 Botucatu, São Paulo, Brasil.

3) Espeleo Grupo de Brasília. Caixa Postal 468, 70359-970 Brasília, Distrito Federal, Brasil. 
Os morcegos passam boa parte de sua vida em seus abrigos (KUNZ 1982; ALTRINGHAM 1996) e algumas espécies chegam a permanecer neles por cerca de 20 horas diariamente (RANSOME 1990). Os hábitos de se abrigar podem influenciar a distribuição local e global das espécies, as densidades de suas populações, as estratégias de forrageamento e de acasalamento, sua estrutura social, os deslocamentos sazonais, e, até mesmo, a morfologia e fisiologia dos morcegos (ALTRINGHAM 1996). Assim, a natureza de um abrigo escolhido pelos morcegos pode ser crucial para sua sobrevivência numa dada área (RANSOME 1990). Os morcegos podem utilizar os mais diversos tipos de abrigo, como cavernas, fendas-de-rocha, buracos no solo, ocos-de-árvore, superfície de troncos de árvore, folhagem, cupinzeiros e construções humanas, como forros de casa, sotãos, porões, janelas, vãos de dilatação, pontes e outros (KUNZ 1982).

Para os diversos grupos de animais que têm sido encontrados no interior de cavernas, esses ambientes podem representar abrigo, fornecendo um local para repouso, reprodução e proteção contra adversidades climáticas. Os morcegos são alguns dos poucos vertebrados que tem feito esse uso de modo eficiente e permanente (KUNZ 1982). Há poucas exceções entre os grupos de peixes, anfíbios e aves (AltringHAm 1996). A utilização desses ambientes como abrigo por parte dos morcegos é um fenômeno antigo. Segundo JEPSEN (1970), os primeiros morcegos tornaram-se habitantes de cavernas para escapar de predadores e ainda, para conservar umidade e energia durante os períodos de grande atividade. As cavernas são consideradas como abrigos permanentes e os mais estáveis para os morcegos (KunZ 1982; Altringham 1996). Por causa desses fatores e das vantagens termoregulatórias, certas espécies de morcegos tendem a formar grandes colônias em ambientes cavernícolas (ALTRINGHAM 1996) e/ou viver em coabitação com outras espécies (KunZ 1982; TRAJANO 1985, 1995). Algumas cavernas do sul dos Estados Unidos da América do Norte abrigam colônias de milhares de morcegos insetívoros (Tadarida brasiliensis, ver KUNZ 1982; Altringham 1996). Por outro lado, existem cavernas que abrigam pequenos grupos ou mesmo somente alguns morcegos (AlTRINGHAM 1996), independentemente de suas dimensões. Assim, o tamanho das colônias de morcegos parece depender mais das características biológicas das espécies do que das características das cavernas.

Uma única caverna pode oferecer uma diversidade grande de microclimas e de formações diversas (escavações laterais, fendas nas paredes, concavidades no teto, etc), permitindo que sejam colonizadas por diversas espécies que requerem necessidades básicas diferentes (Altringham 1996). Segundo Trajano (1985), coabitação seria o uso comum e simultâneo de um abrigo por diferentes espécies e sua ocorrência é previsível quando se considera a grande diversidade e abundância dos quirópteros e o número limitado de abrigos existentes. Essas associações interespecíficas ocorrem habitualmente entre os morcegos, principalmente entre aqueles que utilizam abrigos internos, como cavernas. A maioria dessas associações parece ser casual, talvez resultante do número limitado de abrigos acessíveis ou da convergência de necessidades de temperatura, umidade e escuridão (KUNZ 1982). É de se esperar que as espécies mais comuns sejam também as mais versáteis na utilização de abrigos diferentes e na associação com outras espécies. TRAJANO 
(1985) verificou que nas cavernas do Alto Ribeira, estado de São Paulo, as espécies mais abundantes e de maior ocorrência nas cavernas eram também as que coabitavam com um maior número de outras espécies. A mesma autora não encontrou qualquer correlação entre o número de espécies em coabitação e as características morfométricas das cavernas estudadas por ela no Alto Ribeira.

$\mathrm{O}^{\prime}$ conceito de cavernas (cavidades naturais subterrâneas) que empregamos no presente estudo é aquele utilizado pelo governo brasileiro (BRASIL 1990), que considera cavernas como sendo todo espaço subterrâneo penetrável pelo homem, com ou sem abertura identificada, incluindo seu ambiente, seu conteúdo mineral e hídrico, a fauna e a flora ali encontrados e o corpo rochoso onde a mesma se insere, desde que sua formação tenha sido por processos naturais, independentemente de suas dimensões ou do tipo de rocha encaixante. Desse modo, estão incluídos nessa designação os termos regionais brasileiros, tais como gruta, lapa, toca, abismo, furna, buraco, etc. No presente estudo, consideramos todos os termos acima como sinônimos de cavernas.

No Brasil, a quiropterofauna cavernícola começou a ser mais estudada a partir da década de 80 , quando estudos foram desenvolvidos em diversas regiões (TRAJANO \& MOREIRA 1991). Os trabalhos que analisaram esta fauna com mais detalhes foram os de TRAJANO $(1985,1996)$, desenvolvidos nas cavernas do Vale do Alto Ribeira e por isso serão aqui freqüentemente citados. Nesses trabalhos, a referida autora abordou aspectos sobre a localização das colônias nos abrigos, sociabilidade, reprodução, comportamento, coabitação, horários de emergência, padrões de atividade noturna e deslocamentos das espécies entre as cavernas da região, dando especial ênfase ao comportamento de Desmodus rotundus.

Na região do Distrito Federal, a fauna de morcegos cavernícolas é pouco conhecida, sendo encontrado os trabalhos de COIMBRA et al. (1982) e BAUMGARTEN \& VIEIRA (1994). O primeiro apresenta alguns dados sobre comportamento de alguns morcegos nas grutas de Sobradinho (Distrito Federal) e Mambai (Goiás), e o segundo, aspectos reprodutivos de Anoura geoffroyi em uma das cavernas do Distrito Federal, não identificada pelos autores.

No presente trabalho, estudamos as espécies de morcegos que foram capturadas em 20 cavernas da região do Distrito Federal. Analisamos a freqüência de ocorrência, distribuição dos morcegos no interior das cavidades, composição sexual, estágio reprodutivo, épocas do ano de ocorrência nos abrigos e coabitação com outras espécies de morcegos. Finalmente tecemos algumas considerações sobre a conservação das cavernas e das espécies de morcegos da região do Distrito Federal.

\section{Área de estudo}

A área de estudo está compreendida, em grande parte, no território do Distrito Federal ( $15^{\circ} 30^{\prime}-16^{\circ} 03^{\prime} \mathrm{S} ; 47^{\circ} 25^{\prime}-48^{\circ} 12^{\prime} \mathrm{W}$; cerca $1.200 \mathrm{~m}$ de altitude; área de 5.783 $\mathrm{km}^{2}$ ), situado no Planalto Central, centro-oeste do Brasil. As cavidades naturais estudadas estão concentradas na área norte do Distrito Federal; apenas três delas (Gruta Morro, Toca da Gameleira e Gruta das Orquídeas) estão localizadas em Goiás, município de Padre Bernardo (Fig. 1). 

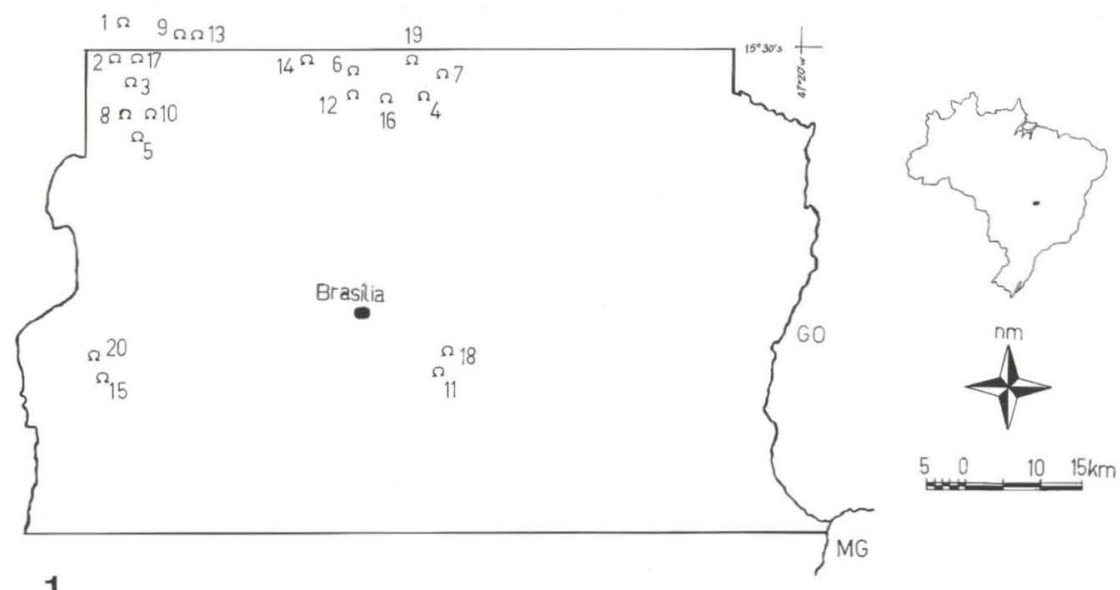

Fig. 1. Mapa da área do Distrito Federal mostrando a localização das cavidades naturais estudadas. Note que três cavernas estão situadas fora dos limites geopoliticos do Distrito Federal. (1) Gruta Morro, (2) Gruta do Sal, (3) Gruta Fenda II, (4) Gruta Dança dos Vampiros, (5) Gruta Dois Irmãos, (6) Gruta da Saúva, (7) Gruta Água Rasa, (8) Gruta da Barriguda, (9) Toca da Gameleira, (10) Gruta Labirinto da Lama, (11) Gruta Volks Clube, (12) Gruta dos Morcegos, (13) Gruta das Orquídeas, (14) Gruta Kipreste, (15) Toca do Falcão, (16) Gruta Mogi, (17) Gruta Muralha, (18) Toca Mata da Anta, (19) Gruta Boca do Lobo e (20) Fenda do Barreiro.

O tipo de relevo mais freqüente nesta região são as chapadas, que apresentam uma altitude média de $1.000 \mathrm{~m}$ decrescendo até os $800 \mathrm{~m}$, próximo a talvegues (CODEPLAN 1984). As quatro principais bacias de drenagem do Distrito Federal são a do rio Preto, a leste, do rio Descoberto, a oeste, do rio São Bartolomeu, a centro-leste e do rio Maranhão ao norte (CODEPLAN 1984). Esta última, afluente da bacia do Araguaia-Tocantins, encampa $80 \%$ das cavidades estudadas, estando o restante das cavernas nas bacias do rio Descoberto ou do rio São Bartolomeu, ambas afluentes do rio Paraná. A região de estudo é caracteristicamente irrigada por ribeirões e córregos perenes.

A vegetação predominante é do tipo cerrado, com faixas de mata-galeria bem preservada ao longo dos cursos d'água (CODEPLAN 1984). Florestas mesofíticas de interflúvio estão restritas ao norte do Distrito Federal, na bacia do rio Maranhão, associadas à ocorrência de calcário (EITEN 1990). Conforme a classificação de Köppen, o clima do Distrito Federal é tropical com duas estações bem distintas: uma chuvosa e quente, de outubro a abril, e outra seca e fria, de maio a setembro (CODEPLAN 1984).

A geologia compreende rochas pré-cambrianas do Grupo Bambuí, formação Paraopeba, constituída predominantemente de siltitos, argilitos, ardósias, arenitos e calcários (DNPM 1981). Os principais afloramentos calcários ocorrem nas regiões dos rios do Sal, Palma, Contagem e do córrego do Ouro (DNPM 1981), todos ao norte da região onde se encontra a maioria das cavernas conhecidas no Distrito Federal. No centro-sul, ocorrem litologias do Grupo Araxá, também do pré-Cam- 
briano. Rochas do Terciário e Quaternário ocorrem a sudeste, na região da Toca do Falcão e da Fenda do Barreiro, onde cobrem quartzitos do Grupo Araxá. A área de estudo enquadra-se na Província Espeleológica do Bambuí, Distrito Espeleológico de Brasília (KARMANN 1979), que possuia 74 cavernas cadastradas em 1996 na Sociedade Brasileira de Espeleologia. Esta região ainda não foi adequadamente estudada.

De modo geral, as cavidades naturais estudadas caracterizam-se por serem predominantemente horizontais e secas, com exceção da Gruta Dança dos Vampiros, Gruta Água Rasa e Gruta dos Morcegos que são percorridas permanentemente por cursos d'água, e a Gruta Volks Clube, percorrida por curso temporário. Do total, 14 são em rocha calcária, duas em micaxisto, duas em quartzito, uma em dolomito e outra em argilito. A maior parte delas $(60 \%)$ é de pequenas dimensões, com menos de $100 \mathrm{~m}$ de desenvolvimento. Das restantes, $25 \%$ apresenta de 100 a $300 \mathrm{~m}$ de desenvolvimento e $15 \%$, mais de $300 \mathrm{~m}$.

\section{MATERIAL E MÉTODOS}

O presente estudo foi desenvolvido no período de novembro de 1989 a dezembro de 1995, abrangendo 20 cavidades naturais. A maior parte destas cavernas foi explorada e topografada pelo Espeleo Grupo de Brasília (EGB) e Grupo Espeleológico da Geologia (GREGEO-UnB) e todas foram cadastradas junto à Sociedade Brasileira de Espeleologia. No cadastro, cada cavidade recebeu um código identificador contendo a sigla da unidade federativa em que se encontra localizada e um número de registro.

No período de estudo, foram realizadas 96 visitas às cavernas da região em geral com duas a três visitas a cada cavidade, tanto na estação seca (49) como na chuvosa (47). No período vespertino, habitualmente entre 15:30 e 17:30 h, o interior de cada cavidade era examinado para localizar agrupamentos de morcegos e verificar sua distribuição espacial e o tamanho aproximado de cada agrupamento. A medida desse tamanho era feita através de contagem direta ou da estimativa do seu número de indivíduos. As capturas eram feitas principalmente com redes de espera ("mist nets"), estendidas na entrada das cavernas, em horário compreendido entre o entardecer (cerca 15 a 30 minutos antes do por-do-sol) e $20: 30 \mathrm{~h}$ ou 21:30 h. Em diversas ocasiões, fizemos uso do puçá no interior dessas cavidades. Após serem capturados, os morcegos foram examinados para determinação do sexo, idade (juvenil ou adulto) e estado reprodutivo. Nos machos, foi examinado a posição dos testículos (escrotada ou abdominal), sendo considerados os primeiros como sexualmente ativos e os segundos como inativos. As fêmeas tiveram seu abdome apalpado para verificar a presença de feto, sendo consideradas como fêmeas grávidas somente aquelas com feto perceptivel por palpação. Ao final da coleta, as redes eram recolhidas e grande parte dos morcegos era solta logo após ser examinada. Exemplares (menos de 10\%) foram mantidos como espécimes-testemunho na coleção da Gerência de Controle de Zoonoses do Distrito Federal.

Para efeito de padronização, consideramos como espécies residentes nas cavernas somente aquelas capturadas enquanto saiam para sua atividade noturna 
e/ou observadas em seu interior. As espécies capturadas somente enquanto adentravam a caverna e não observadas no interior das mesmas (aqui consideradas como não-residentes) não foram incluídas na análise de coabitação com outras espécies.

Em cada cavidade, foi observada a existência ou não de ações antrópicas, aqui denominadas de "fatores de perturbação". Esses fatores, modificando o interior ou o exterior imediato das cavernas, podem influenciar os agrupamentos de morcegos em seu interior.

\section{RESULTADOS E DISCUSSÃO}

\section{Cavernas e sua Comunidade de Morcegos na região do Distrito Federal}

Segue-se a lista das cavernas estudadas com a localização e uma breve descrição das mesmas, os meses em que foram visitadas para coletas das espécies residentes e não-residentes (entre parênteses, o número de exemplares capturados, separados por sexo) e, sempre que disponível, observações sobre a distribuição das colônias no interior das cavernas. A seqüência de apresentação das cavernas segue a ordem decrescente da riqueza de espécies residentes de morcegos e/ou das dimensões das cavidades.

\section{Gruta Morro (GO 072), Goiás, Padre Bernardo, Fazenda Cristal (152' S $48^{\circ} 09^{\prime} \mathrm{W}$; altitude $840 \mathrm{~m}$ )}

Gruta calcária seca com $58 \mathrm{~m}$ de desenvolvimento em conduto único com pequena dimensão e apenas uma entrada; distante $10 \mathrm{~m}$ do córrego do Morro; vegetação externa do tipo mata-galeria. Fatores de perturbação identificados: nenhum.

Época das coletas: agosto/91, abril e agosto/92, abril e dezembro/93, fevereiro e dezembro/95.

Espécies residentes: D. rotundus (123 machos, 133 fêmeas), G. soricina (41 machos, 52 fêmeas), C. perspicillata ( 80 machos, 68 fêmeas), M. bennettii (2 machos, 3 fêmeas), D. ecaudata (16 machos, 10 fêmeas), $P$. hastatus (12 machos, 5 fêmeas), P. parnellii (13 machos, 1 fềmea), L. aurita (44 machos) e M. megalotis (1 fềmea).

Espécies não-residentes: $L$. dekeyseri ( 2 machos, 1 fêmea), A. caudifer (5 machos, 1 fêmea), P. lineatus (1 macho, 2 fêmeas) e E. brasiliensis (1 macho).

Gruta do Sal (DF 005), Distrito Federal, Brazlândia, Fazenda Palestina (1530'S, 48¹0'W; altitude $805 \mathrm{~m}$ )

Gruta calcária seca com $341 \mathrm{~m}$ de desenvolvimento, com um salão de médio volume interno, vários condutos menores e duas amplas entradas; vegetação externa do tipo mata mesofítica de interflúvio, circundada por cerrado e pasto. Fatores de perturbação identificados: visitação freqüente.

Época das coletas: junho e outubro/92, março/93 e novembro/94.

Espécies residentes: D. rotundus (64 machos, 38 fêmeas), G. soricina (3 
machos, 5 fềmeas), C. perspicillata (6 machos, 2 fêmeas), $M$. bennettii (3 fêmeas), $P$. macrotis (1 macho, 4 fềmeas), D. ecaudata (4 machos), $P$. hastatus (4 machos, 18 fềmeas) e $T$. cirrhosus (5 machos, 3 fêmeas).

Gruta Fenda II (DF 016), Distrito Federal, Brazlândia, Fazenda Palestina (1530'S, $48^{\circ} 10^{\prime} \mathrm{W}$; altitude $814 \mathrm{~m}$ )

Gruta calcária seca com $432 \mathrm{~m}$ de desenvolvimento labiríntico com volume interno pequeno e duas entradas de pequena amplitude; situada a cerca $80 \mathrm{~m}$ de distância da Gruta do Sal; vegetação externa do tipo mata mesofítica de interflúvio, circundada por cerrado. Fatores de perturbação identificados: nenhum.

Época das coletas: junho e outubro/92, março/93, janeiro, julho e novembro/94.

Espécies residentes: D. rotundus ( 88 machos, 98 fềmeas), G. soricina (1 macho, 2 fêmeas), C. perspicillata (4 machos, 10 fêmeas), M. bennettii (1 macho, 2 fềmeas), D. ecaudata (1 macho), L. dekeyseri (5 machos, 19 fêmeas) e T. cirrhosus (8 machos, 2 fềmeas).

Espécie não-residente: $P$. lineatus (1 macho).

Gruta da Saúva (DF 003), Distrito Federal, Sobradinho, Fazenda Sete Lagoas (1532'S, 4752'W; altitude $800 \mathrm{~m}$ )

Gruta calcária seca com $235 \mathrm{~m}$ de desenvolvimento, com três segmentos paralelos interligados por condutos secundários; acessada por uma entrada pequena e ventilação precária; vegetação externa do tipo mata-galeria.. Fatores de perturbação identificados: visitação esporádica.

Época das coletas: novembro/89, outubro/91, abril e setembro/92, março, abril e setembro/93, julho/94 e novembro/95.

Espécies residentes: D. rotundus ( 73 machos, 45 fêmeas), G. soricina (13 machos, 8 fêmeas), C. perspicillata ( 25 machos, 16 fêmeas), M. bennettii ( 2 machos, 2 fêmeas), D. ecaudata ( 10 machos, 25 fêmeas), L. dekeyseri ( 16 machos, 43 fềmeas) e M. megalotis (1 macho, 1 fêmea).

Gruta Dança dos Vampiros (DF 007), Distrito Federal, Planaltina, nas

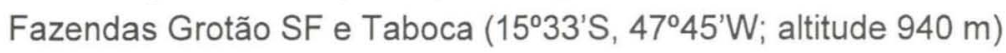

Gruta calcária de $223 \mathrm{~m}$ de desenvolvimento percorrida pelo ribeirão Taboca, em um conduto único e bem ventilado; possui três entradas, uma em cada extremidade da galeria e outra ao centro (entrada em abismo); vegetação externa do tipo mata-galeria. Fatores de perturbação identificados: nenhum.

Época das coletas: julho e outubro/92 e agosto/94.

Espécies residentes: D. rotundus (23 machos, 24 fêmeas), G. soricina (2 machos), C. perspicillata (7 machos, 17 fềmeas), A. geoffroyi (97 machos, 28 fêmeas), C. auritus (1 fềmea), $P$. parnellii ( 60 machos, 23 fềmeas) e $P$. gymnonotus (1 macho).

Espécies não-residentes: $L$. dekeyseri (1 fềmea) e $M$. nigricans (2 machos). 
Observação: a distribuição espacial de cinco das espécies residentes no interior da gruta pode ser observada na figura 2. Em março de 1997, um agrupamento de $L$. dekeyseri foi observado durante o dia abrigando-se no interior da caverna, proximo das colônias de G. soricina e C. perspicillata.

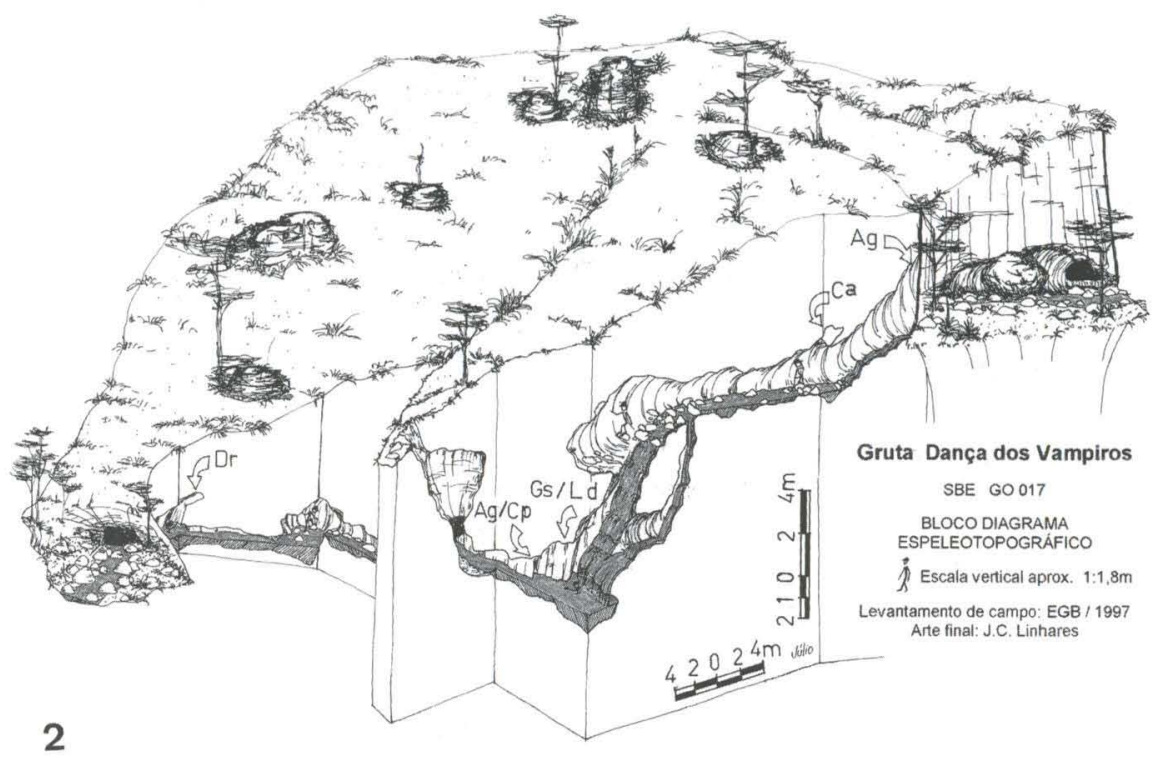

Fig. 2. Mapa, em perfil longitudinal, da Gruta Dança dos Vampiros de $223 \mathrm{~m}$ de desenvolvimento, mostrando a distribuição dos agrupamentos de seis espécies de morcegos observados em seu interior. Note as três entradas, situadas nas extremidades e no centro, entrada em abismo, e o ribeirão Taboca no interior da caverna. (Dr) Desmodus rotundus, (Gs) Glossophaga soricina, (Cp) Carollia perspicillata, $(\mathrm{Ag})$ Anoura geoffroyi, (Ca) Chrotopterus auritus.

\section{Gruta Dois Irmãos (DF 012), Distrito Federal, Brazlândia, Fazenda Dois Irmãos (15⒊'S, 4807'W, altitude $840 \mathrm{~m}$ )}

Gruta calcária seca com $90 \mathrm{~m}$ de desenvolvimento, composta por vários pequenos salões em dois níveis sobrepostos e uma entrada; inserida em morro calcário encoberto por vegetação do tipo mata mesofítica de interflúvio e circundado por cerrado e lavouras. Fatores de perturbação identificados: desmatamento do cerrado próximo e visitação.

Época das coletas: maio e setembro/92, março e setembro/93, janeiro e agosto/94,

Espécies residentes: D. rotundus ( 85 machos, 60 fêmeas), G. soricina (6 machos, 15 fềmeas), $C$. perspicillata ( 6 machos, 3 fêmeas), $M$. bennettii (4 machos, 5 fêmeas), $P$. macrotis ( 5 machos, 8 fêmeas) e $P$. hastatus ( 2 machos, 1 fềmea) e $L$. dekeyseri (4 machos, 19 fêmeas).

Espécies não-residentes: L. aurita (1 macho) e $P$. lineatus (1 macho).

Observação: a distribuição espacial das sete espécies residentes na gruta pode ser vista na figura 3. 


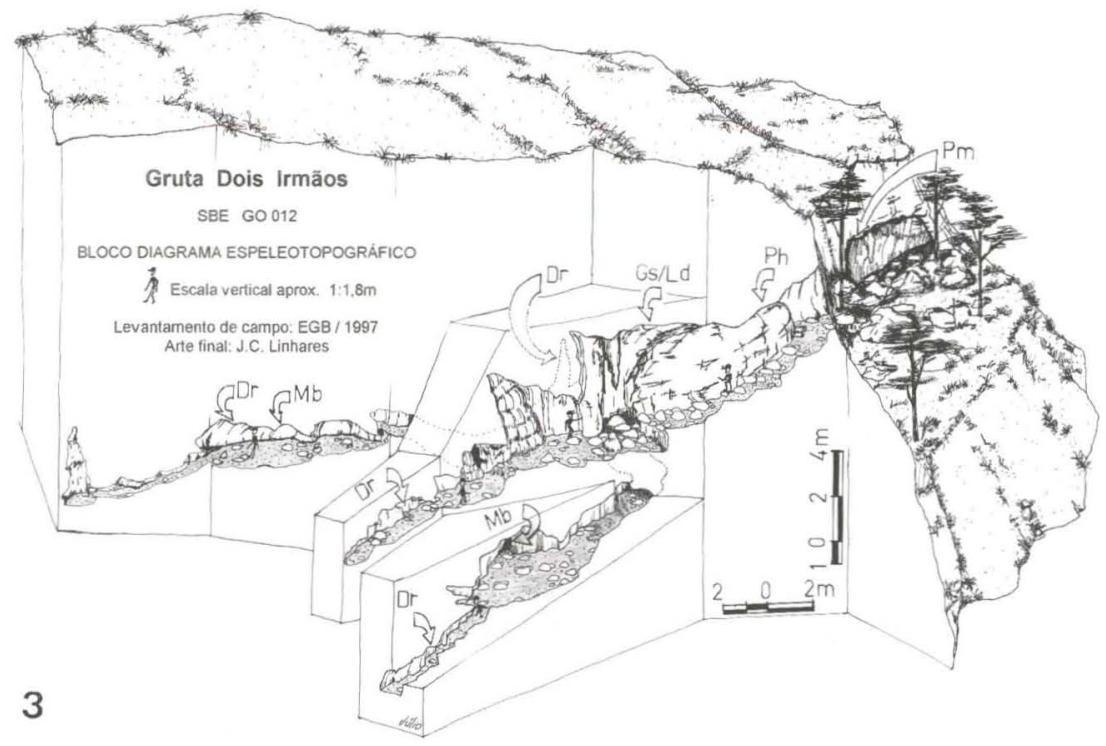

Fig. 3. Mapa, em perfil longitudinal, da Gruta Dois Irmãos de $90 \mathrm{~m}$ de desenvolvimento e uma entrada. Note que os agrupamentos de sete espécies de morcegos distribuem pelos pequenos salões. (Dr) Desmodus rotundus, (Gs) Glossophaga soricina, (Cp) C. Perspicillata, (Mb) Mimon bennettii, (Pm) Peropteryx macrotis, (Ph) Phyllostomus hastatus, (Ld) Lonchophylla dekeyseri.

\section{Gruta Água Rasa (DF 018), Distrito Federal, Planaltina, Fazenda Grotão SF $\left(15^{\circ} 32^{\prime} \mathrm{S}, 47^{\circ} 44^{\prime} \mathrm{W}\right.$, altitude $\left.860 \mathrm{~m}\right)$}

Gruta calcária com $101 \mathrm{~m}$ de desenvolvimento entre o sumidouro e a ressurgência em conduto amplo; com pequenos condutos laterais, normalmente secos, que acessam uma terceira entrada; com duas distintas zonas de luz, uma de penumbra com variação da intensidade de penetração luminosa, representada pelo conduto principal e outra de escuridão total, caracterizada pelos pequenos condutos laterais; vegetação externa do tipo mata-galeria, que se estende pelo talvegue, onde o acidentado relevo local dificulta o estabelecimento de lavouras e pasto, preservando as matas. Fatores de pertubação identificados: nenhum.

Época das coletas: agosto/90, junho e outubro/92 e maio/93.

Espécies residentes: D. rotundus (17 machos, 13 fêmeas), G. soricina (1 macho), P. hastatus (20 machos, 8 fêmeas), A. geoffroyi (60 machos, 86 fêmeas), $F$. horrens (2 machos, 1 fềmea) e P. stenops (1 fềmea).

Espécies não-residentes: $C$. perspicillata (2 machos) e $P$. lineatus (1 macho).

Gruta da Barriguda (DF 011), Distrito Federal, Brazlândia, Fazenda Pontal dos Angicos ( $15^{\circ} 33^{\prime} \mathrm{S}, 48^{\circ} 07^{\prime} \mathrm{W}$; altitude $840 \mathrm{~m}$ )

Gruta calcária seca com $57 \mathrm{~m}$ de desenvolvimento em amplo salão, provido de uma grande entrada; vegetação externa do tipo mata mesofítica de interflúvio. Fatores de perturbação identificados: nenhum. 
Época das coletas: julho e outubro/92, março/93 e janeiro/94

Espécies residentes: D. rotundus (3 machos), $G$. soricina (3 fêmeas), $M$. bennettii (3 machos, 1 fềmea), $P$. macrotis (indivíduos apenas observados), $P$. hastatus (2 machos) e $C$. auritus (1 macho, 1 fêmea).

Espécies não-residentes: C. perspicillata (2 machos) e M. nigricans (2 machos, 1 fêmea).

Toca da Gameleira (GO 113), Goiás, Padre Bernardo, Fazenda Pontal dos

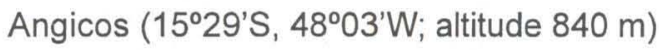

Pequena cavidade calcária seca com $20 \mathrm{~m}$ de desenvolvimento terminando em um único salão; vegetação externa do tipo mata mesofítica de interflúvio. Fatores de perturbação identificados: nenhum.

Época das coletas: abril, agosto e outubro/91, abril e outubro/92, junho/93, junho/94 e março/95.

Espécies residentes: D. rotundus (2 machos, 1 fêmea), G. soricina (3 machos), C. perspicillata (10 machos, 2 fềmeas), $P$. macrotis (3 fềmeas), $D$. ecaudata (3 machos) e $F$. horrens (36 machos, 17 fêmeas).

Espécies não-residentes: M. megalotis (2 fêmeas) e $P$. lineatus (3 machos).

Gruta Labirinto da Lama (DF 010), Distrito Federal, Brazlândia, Fazenda Pontal dos Angicos ( $15^{\circ} 33^{\prime} \mathrm{S} 48^{\circ} 07^{\prime} \mathrm{W}$; altitude $840 \mathrm{~m}$ )

Gruta calcária geralmente seca, porém inundada parcialmente entre os meses de abril e junho; desenvolve-se por $260 \mathrm{~m}$ em condutos labirínticos e de pequenas dimensões; entrada pequena, pouca ventilação e zona afótica em boa parte de sua extensão; vegetação externa do tipo mata-galeria, cercada por pastos; distante $30 \mathrm{~m}$ do córrego Dois Irmãos. Fatores de perturbação identificados: nenhum.

Época das coletas: julho e outubro/92, março/93 e janeiro/94.

Espécies residentes: D. rotundus (3 machos, 1 fêmea), G. soricina (1 macho, 5 fềmeas), $P$. macrotis (1 fềmea) e C. auritus (espécie apenas observada).

Espécie não-residente: $C$. perspicillata (1 macho).

Gruta Volks Clube (DF 007), Distrito Federal, Paranoá, Loteamento Boca da Mata (1552'S, 47²4'W; altitude $1.200 \mathrm{~m}$ )

Gruta seca em argilito com $84 \mathrm{~m}$ de desenvolvimento em um único conduto e uma entrada em cada extremidade; vegetação externa tipo mata-galeria e cerrado. Fatores de perturbação identificados: gruta situada junto a loteamento residencial em área peri-urbana e com visitas constantes.

Época das coletas: julho/89, fevereiro e outubro/92, fevereiro/93, maio e novembro/94.

Espécies residentes: D. rotundus ( 8 machos), G. soricina (4 machos), $A$. geoffroyi (20 machos, 16 fêmeas) e C. auritus (1 macho).

Espécies não-residentes: C. perspicillata (1 macho), L. aurita (1 macho), $A$. caudifer (1 macho) e $M$. nigricans (1 macho, 3 fềmeas).

Observação: em novembro de 1994, a quiropterofauna não foi encontrada. 


\section{Gruta dos Morcegos (DF 013), Distrito Federal, Sobradinho, Fábrica de Cimento Tocantins ( $15^{\circ} 33^{\prime} \mathrm{S}, 47^{\circ} 52^{\prime} \mathrm{W}$; altitude $830 \mathrm{~m}$ )}

Gruta calcária com um pequeno curso d'água permenente em seus $93 \mathrm{~m}$ de desenvolvimento; em conduto único e estreito; apresenta quatro entradas; vegetação externa do tipo mata-galeria. Fatores de perturbação identificados: detonações próximas, para retirada de calcário (mineração).

Época das coletas: junho/92 e março/95.

Espécies residentes: D. rotundus (10 machos, 1 fêmea), G. soricina (1 fềmea) e A. geoffroyi (1 macho).

Gruta Kipreste (DF 020), Distrito Federal, Sobradinho, Fazenda Ribeirão (1530'S $47^{\circ} 57^{\prime} \mathrm{W}$; altitude $827 \mathrm{~m}$ )

Gruta calcária seca com 378 m de desenvolvimento por condutos fendulares; apresentando duas entradas; vegetação externa do tipo cerrado. Fatores de perturbação identificados: nenhum.

Época das coletas: junho e outubro/92.

Espécies residentes: G. soricina (2 machos, 2 fêmeas) e P. macrotis (1 macho, 1 fêmea).

Espécie não-residente: $M$. nigricans (1 macho, 2 fêmeas).

Toca do Falcão (DF 026), Distrito Federal, Ceilândia, Fazenda Três Lagoas (1552'S, 48¹1'W; altitude $800 \mathrm{~m}$ )

Gruta quartzítica seca, com $35 \mathrm{~m}$ de desenvolvimento em uma única fenda com largura média de um metro e meio e uma entrada ampla; vegetação externa do tipo mata-galeria. Fatores de perturbação identificados: nenhum.

Época das coletas: abril, agosto e novembro/93, outubro/94 e outubro/95.

Espécies residentes: D. rotundus ( 56 machos, 1 fềmea) e C. perspicillata (15 machos, 6 fêmeas).

Espécies não-residentes: G. soricina ( 9 machos, 7 fềmeas), L. dekeyseri (4 machos, 4 fêmeas), A. caudifer (5 machos, 1 fềmea) e $M$. minuta (1 macho).

Gruta Mogi (DF 014), Distrito Federal, Sobradinho, Fazenda Recreio Mogi (153' $\mathrm{S}, 47^{\circ} 49^{\prime} \mathrm{W}$; altitude $800 \mathrm{~m}$ )

Gruta seca em micaxisto com $34 \mathrm{~m}$ de desenvolvimento, com conduto único e uma entrada; situada às margens do córrego Mogi; vegetação externa do tipo mata-galeria. Fatores de perturbação identificados: nenhum.

Época das coletas: maio e setembro/92, setembro/93, janeiro e julho/94.

Espécies residentes: $D$. rotundus (48 machos, 58 fêmeas) e $F$. horrens (1 macho, 2 fêmeas).

Espécies não-residentes: $G$. soricina (1 macho, 2 fêmeas), $C$. perspicillata (2 machos, 2 fềmeas), D. ecaudata (1 macho), M. megalotis (1 fềmea) e A. caudifer (1 macho). 
Gruta Muralha (DF 006), Distrito Federal, Brazlândia, Fazenda Palestina (1530'S, 4809'W; altitude $910 \mathrm{~m}$ )

Gruta seca em dolomito com $30 \mathrm{~m}$ de desenvolvimento, em um salão inicial e um conduto lateral e uma entrada; vegetação externa do tipo mata-galeria. Fatores de perturbação identificados: nenhum.

Época das coletas: junho e outubro/92, junho/93 e junho/94.

Espécies residentes: G. soricina (2 machos) e $F$. horrens (4 machos, 14 fêmeas).

Toca Mata da Anta (DF 28), Distrito Federal, Paranoá, Loteamento Mata da Anta ( $15^{\circ} 51^{\prime} \mathrm{S}, 47^{\circ} 47^{\prime} \mathrm{W}$; altitude $1.200 \mathrm{~m}$ )

Gruta seca em micaxisto, dividida em dois segmentos distintos, o primeiro em teto baixo num salão fechado com $10 \mathrm{~m}$ de desenvolvimento e o segundo em um túnel, aberto nas duas extremidades; vegetação externa do tipo mata-galeria. Fatores de perturbação identificados: visitação esporádica somente ao túnel.

Época das coletas: setembro/92, fevereiro/93 e novembro/94.

Espécies residentes: $D$. rotundus (14 machos, 23 fềmeas) e G. soricina (2 machos, 4 fềmeas).

Espécie não-residente: $A$. caudifer (1 macho).

Observação. a primeira espécie abrigava-se no salão e a segunda, no túnel.

Gruta Boca do Lobo (DF023), Distrito Federal, Sobradinho, Fazenda Limoeiro (1530'S, 47047'W; altitude $780 \mathrm{~m}$ )

Gruta calcária seca com $147 \mathrm{~m}$ de desenvolvimento por conduto único e duas entradas próximas entre si; vegetação externa do tipo mata mesofítica de interflúvio. Fatores de perturbação identificados: mineração de calcário na face posterior do morro.

Época das coletas: julho e outubro/92.

Espécie residente: $D$. rotundus (12 machos, 29 fêmeas).

Gruta das Orquídeas (GO 112), Goiás, Padre Bernardo, Fazenda Lagoa $\left(15^{\circ} 29^{\prime} \mathrm{S}, 48^{\circ} 04^{\prime} \mathrm{W}\right.$; altitude $\left.840 \mathrm{~m}\right)$

Gruta calcária seca com $35 \mathrm{~m}$ de desenvolvimento, duas entradas, sendo uma delas em abismo, que derivam para três pequenos salões fendulares; vegetação externa do tipo mata mesofítica de interflúvio. Fatores de perturbação identificados: nenhum.

Época das coletas: julho/93, abril e agosto/94 e março/95.

Espécie residente: $D$. rotundus (51 machos, 63 fêmeas).

Espécies não-residentes: $G$. soricina (1 macho, 4 fêmeas), $D$. ecaudata (1 fêmea) e $P$. lineatus (1 macho, 1 fêmea). 
Fenda do Barreiro (DF 027), Distrito Federal, Ceilândia, Fazenda Três Lagoas (1551'S, 4811'W; altitude $800 \mathrm{~m}$ )

Gruta quartizítica seca com $20 \mathrm{~m}$ de desenvolvimento em fendas estreitas e duas entradas pequenas; vegetação externa do tipo mata-galeria. Fatores de perturbação identificados: visitação freqüente.

Época das coletas: maio, agosto e novembro/93, agosto, outubro e dezembro/94, março e outubro/95.

Espécie residente: D. rotundus (195 machos, 192 fêmeas).

Espécies não-residentes: $G$. soricina ( 7 machos, 8 fêmeas), C. perspicillata (3 machos, 3 fềmeas), A. caudifer (2 fêmeas) e $M$. nigricans ( 1 macho, 5 fêmeas).

Observação: aparentemente as espécies não-residentes abrigavam-se em pequenas escavações nos barrancos do rio, localizado perto desta gruta.

\section{Análise da Riqueza de Espécies e Composição das Comunidades de Morcegos das Cavernas da Região do Distrito Federal}

No Brasil, cerca de 35 espécies de morcegos já foram encontradas vivendo em cavernas, representando $25,5 \%$ do número total de espécies registradas em território brasileiro (TRAJANO 1995). Segundo a mesma autora, esse número deve ser muito maior pois em muitas áreas a fauna de morcegos das cavernas foi pouco estudada. No México, $45 \%$ das espécies de morcegos se abrigam regularmente em cavernas, proporção semelhante (46\%) à encontrada nos E.U.A. (ARITA 1993; ARITA \& VARGAS 1995). Das 35 espécies anteriormente conhecidas por habitar cavidades naturais do Brasil, capturamos 22 nas cavernas da região do Distrito Federal (Tab. I); porém, consideramos apenas 17 como espécies residentes, isto é, aquelas que estavam utilizando cavernas como abrigo diurno. Há um predomínio nítido da família Phyllostomidae, entre as cinco famílias encontradas, com 13 espécies residentes (76\%) e 92\% dos indivíduos capturados nas cavidades estudadas. No México, os filostomídeos perfazem quase $52 \%$ das espécies cavernícolas (ARITA 1993). Nas cavernas do estado de São Paulo, a maior parte das espécies residentes também pertencia a esta família (ver TRAJANO 1985; CAMPANHÃ \& FOWLER 1993). As espécies mais freqüentes nas cavernas do Distrito Federal foram uma hematófaga (D. rotundus, em $90 \%$ das cavernas estudadas), uma nectarívoraonívora (G. soricina, $75 \%$ ) e uma frugivora (C. perspicillata, $40 \%$ ). Uma relação semelhante foi encontrada por TRAJANO (1985) nas cavernas do Alto Ribeira: uma hematófaga (D. rotundus, 65,6\%), uma frugívora (C. perspicillata, 56,3\%) e uma nectarívora (A. caudifer, 37,5\%). A diferença básica nessas duas listas está na substituição entre espécies nectarívoras, que será discutida posteriormente no item seguinte. Entre as 10 espécies mais freqüentes, oito são Phyllostomidae, inclusive a espécie mais abundante, Desmodus rotundus $(54,7 \%)$.

TRAJANO (1995) comentou que as comunidades cavernícolas brasileiras são especialmente ricas em espécies da subfamília Phyllostominae. Segundo nossos dados, $41 \%$ das espécies residentes em cavernas da região do Distrito Federal pertencem a esta subfamília, sendo que, em $50 \%$ das cavernas estudadas havia no mínimo uma e no máximo quatro espécies de Phyllostominae vivendo em seu interior. 
Tabela I. Número de morcegos, separados por espécies e sexos, e sua freqüência de ocorrência em 20 cavernas da região do Distrito Federal.

\begin{tabular}{|c|c|c|c|c|c|c|}
\hline \multirow{2}{*}{ Espécies } & \multirow{2}{*}{ Familias } & \multicolumn{3}{|c|}{ Individuos } & \multicolumn{2}{|c|}{ Cavidades } \\
\hline & & Machos & Fèmeas & Total & $\mathrm{N}$ & $(\%)^{\circ}$ \\
\hline Desmodus rotundus & Phyllostomidae & 875 & 780 & 1655 & 18 & (90) \\
\hline Glossophaga soricina ${ }^{1}$ & Phyllostomidae & 81 & 97 & 178 & 15 & (75) \\
\hline Carollia perspicillata $^{2}$ & Phyllostomidae & 153 & 124 & 277 & 8 & (40) \\
\hline Mimon bennettii & Phyllostomidae & 12 & 16 & 28 & 6 & (30) \\
\hline Peropteryx macrotis & Emballonuridae & 7 & 17 & 24 & 6 & (30) \\
\hline Diphylla ecaudata ${ }^{3}$ & Phyllostomidae & 34 & 35 & 69 & 5 & (25) \\
\hline Phyllostomus hastatus & Phyllostomidae & 40 & 32 & 72 & 5 & (25) \\
\hline Anoura geoffroyi & Phyllostomidae & 178 & 130 & 308 & 4 & (20) \\
\hline Furipterus horrens & Furipteridae & 43 & 34 & 77 & 4 & (20) \\
\hline Chrotopterus auritus & Phyllostomidae & 2 & 2 & 4 & 4 & (20) \\
\hline Lonchophylla dekeyseri ${ }^{4}$ & Phyllostomidae & 25 & 81 & 106 & 3 & (15) \\
\hline Pteronotus parnellii & Mormoopidae & 73 & 24 & 97 & 2 & (10) \\
\hline Trachops cirrhosus & Phyllostomidae & 13 & 5 & 18 & 2 & (10) \\
\hline Micronycteris megalotis ${ }^{5}$ & Phyllostomidae & 1 & 2 & 3 & 2 & (10) \\
\hline Lonchorhina aurita ${ }^{6}$ & Phyllostomidae & 44 & 0 & 44 & 1 & (5) \\
\hline Pteronotus gymnonotus & Mormoopidae & 1 & 0 & 1 & 1 & (5) \\
\hline Phylloderma stenops & Phyllostomidae & 0 & 1 & 1 & 1 & (5) \\
\hline Anoura caudifer ${ }^{7}$ & Phyllostomidae & 12 & 5 & 17 & 6 & \\
\hline Platymhinus lineatus ${ }^{7}$ & Phyllostomidae & 8 & 3 & 11 & 6 & \\
\hline Myotis nigricans $^{7}$ & Vespertilionidae & 7 & 11 & 18 & 5 & \\
\hline Micronycteris minuta ${ }^{7}$ & Phyllostomidae & 1 & 0 & 1 & 1 & \\
\hline Eptesicus brasiliensis $^{7}$ & Vespertilionidae & 1 & 0 & 1 & 1 & \\
\hline otal & & 1611 & 1399 & 3010 & 20 & \\
\hline
\end{tabular}

*) Os números abaixo (quantidade e espécies) não foram incluídos na análise da freqüência de ocorrência, pois os morcegos foram capturados adentrando cavernas: (1) dezoito machos e vinte e uma fêmeas; (2) onze machos e cinco fêmeas; (3) um macho e uma fêmea; (4) seis machos e seis fêmeas; (5) três fêmeas; (6) dois machos; (7) espécies não analisadas quanto a freqüência de ocorrência.

A riqueza média de espécies residentes nas 20 cavernas estudadas no Distrito Federal foi de 4,4 espécies/caverna (variando de 1 a 9). Para as 11 cavernas do Alto Ribeira, estudadas em detalhes por TRAJANO (1985), calculamos uma riqueza média de 4,0 espécies/caverna (variando de 2 a 8 ). Esse resultado é semelhante ao que obtivemos nas cavernas da região do Distrito Federal, excluídas as cinco espécies consideradas como não-residentes. Dessas cinco, acreditamos que pelo menos três delas (A. caudifer, $P$. lineatus e $M$. nigricans) devem se abrigar diurnamente nas cavernas do Distrito Federal, pois foram capturados vários exemplares de cada espécie, em diversas ocasiões e em cavernas diferentes. Além disso, essas espécies são conhecidas na literatura por também utilizarem cavernas como abrigo diurno (ver TRajano 1987). No México, o número de espécies de morcegos por caverna variou entre um e 13 (ARITA 1993). Porém, apenas $10 \%$ das 215 cavernas mexicanas estudadas continham mais de seis espécies, em coabitação, e a grande maioria $(80 \%)$ continha três ou menos espécies em coabitação (ARITA 1993). Os dados da região do Distrito Federal mostram uma proporção superior (45\%) de cavernas com uma riqueza considerável de espécies (seis ou mais). Acreditamos que esse resultado seja, pelo menos em parte, uma conseqüência de diferença metodológica: nosso trabalho foi desenvolvido ao longo de seis anos, enquanto que o de ARITA (1993), 
em apenas um ano. Uma outra alternativa, não mutuamente exclusiva, é a existência de uma maior riqueza total de espécies na região do Distrito Federal, quando comparada com a estudada por esse autor no México.

As cavernas da região do Distrito Federal apresentaram uma baixa abundância de morcegos, pois poucas colônias continham mais de 100 individuos. É possível que a grande disponibilidade de cavernas na região seja responsável, pelo menos em parte, por esta baixa densidade populacional. TRAJANO (1985) propos a mesma explicação para a densidade relativamente baixa de morcegos das cavernas do Alto Ribeira. A maioria das cavernas brasileiras ocorre em áreas calcárias, mais favoráveis à formação de cavidades naturais e onde as populações de morcegos, na ausência das vantagens da formação de grandes colônias para termorregulação (como ocorre na região temperada), se dispersariam pelo elevado número de abrigos em rocha disponíveis (TRAJANO 1985, 1996). Conseqüentemente, grandes concentrações de morcegos, em geral, ocorrem em cavernas areníticas, bem menos numerosas. Nesse aspecto, Trajano (1995) comentou que as cavernas areníticas amazônicas poderiam ser consideradas como as verdadeiras cavernas de morcegos ("bat caves") do Brasil e conteriam de centenas a milhares de morcegos insetívoros, principalmente de P. parnellii (TRAJANO \& MoreIRA 1991). O ecossistema dessas cavernas estaria baseado na atividade desses morcegos, responsáveis pela importação de quase toda matéria orgânica (na forma de guano) que sustentaria a cadeia trófica cavernícola (TRAJANO \& MOREIRA 1991).

Segundo TRAJANo (1985), coabitação seria o uso comum e simultâneo de um abrigo por diferentes espécies e sua ocorrência é previsível quando se considera a grande riqueza e abundância dos quirópteros e o número limitado de abrigos. No presente estudo, analisamos a coabitação entre pares de espécies de morcegos e a freqüência de ocorrência de cada par de espécies nas 20 cavernas estudadas na região do Distrito Federal (Tab. II). Nessa análise, verificamos que a coabitação ocorreu para todas as espécies estudadas, mesmo para aquelas consideradas como raras e encontradas apenas uma vez, como $P$. gymnonotus e $P$. stenops. TRAJANo (1985) preferiu desconsiderar as espécies muito raras ou registradas uma única vez. Nossas conclusões não diferem das da referida autora, pois as espécies mais abundantes e de maior ocorrência nas cavernas foram logicamente as que mais coabitaram com outras espécies. No presente estudo, o maior índice de coabitação (65\%) ocorreu entre $D$. rotundus e $G$. soricina, justamente as duas espécies de maior freqüência de ocorrência nas cavernas do Distrito Federal. TRAJANO (1985) não encontrou qualquer correlação entre o número de espécies em coabitação e as características morfométricas das cavernas do Alto Ribeira. Nossos dados sugerem que o mesmo parece ocorrer na região do Distrito Federal, pois as cavernas estudadas diferem basicamente em suas dimensões e o número de espécies encontradas aparentemente foi independente das dimensões das cavernas ocupadas. Assim, o número de espécies em uma dada caverna do Distrito Federal provavelmente depende da disponibilidade de outros abrigos e de alimento na vizinhança. Estas espécies têm que conviver com agrupamentos de D. rotundus, independentemente de uma possível maior ou menor afinidade com esta espécie hematófaga (ver discussão em TRAJANO 1985). 
Tab. II. Freqüência de ocorrência (\%) de pares de espécies de morcegos, em coabitação, em 20 cavernas da região do Distrito Federal, estudadas no periodo de 1989 a 1995.

\begin{tabular}{|c|c|c|c|c|c|c|c|c|c|c|c|c|c|c|c|c|c|}
\hline Espécies & rotundus & soricina & perspicillata & bennettii & macrotis & ecaudata & hastatus & geoffroyi & horrens & auritus & dekeyseri & parnellii & cirrhosus & Is megalotis & aurita & gymnonotus & stenops \\
\hline D. rotundus & - & & & & & & & & & & & & & & & & \\
\hline G. soricina & 65 & - & & & & & & & & & & & & & & & \\
\hline C. perspicillata & 40 & 35 & - & & & & & & & & & & & & & & \\
\hline M. bennettii & 30 & 30 & 25 & - & & & & & & & & & & & & & \\
\hline P. macrotis & 25 & 30 & 15 & 15 & - & & & & & & & & & & & & \\
\hline D. ecaudata & 25 & 25 & 25 & 20 & 10 & - & & & & & & & & & & & \\
\hline P. hastatus & 25 & 25 & 15 & 20 & 15 & 10 & - & & & & & & & & & & \\
\hline A. geoffroyi & 20 & 20 & 5 & - & - & - & 5 & - & & & & & & & & & \\
\hline F. horrens & 15 & 15 & 5 & - & 5 & 5 & 5 & 5 & - & & & & & & & & \\
\hline C. auritus & 20 & 20 & 5 & 5 & 10 & - & 5 & 10 & - & - & & & & & & & \\
\hline L. dekeyseri & 15 & 15 & 5 & - & 5 & 5 & 5 & 5 & - & - & - & & & & & & \\
\hline P. parmellii & 10 & 10 & 10 & 5 & - & 5 & 5 & 5 & 5 & - & - & - & & & & & \\
\hline T. cirrhosus & 10 & 10 & 10 & 10 & 5 & 10 & 5 & - & - & 5 & - & - & - & & & & \\
\hline M. megalotis & 5 & 5 & 5 & 5 & - & 5 & 5 & - & - & - & - & 5 & - & - & & & \\
\hline L. aurita & 10 & 10 & 10 & 10 & - & 10 & 5 & - & - & 5 & - & 5 & - & 5 & - & & \\
\hline P. gymnonotus & 5 & 5 & 5 & - & - & - & - & 5 & 5 & - & - & 5 & - & - & - & - & \\
\hline P. stenops & 5 & 5 & - & - & - & - & 5 & 5 & - & - & 5 & - & - & - & - & - & - \\
\hline
\end{tabular}




\section{Informações Biológicas dos Morcegos Cavernicolas da Região do Distrito Federal}

As 17 espécies de morcegos residentes estão aqui ordenadas de acordo com sua freqüência de ocorrência nas cavidades do Distrito Federal (ver Tab. I). Informações biológicas sobre as cinco espécies, consideradas no presente estudo como não-residentes em cavernas são também apresentadas, na mesma seqüência da tabela I.

\section{Desmodus rotundus (E. Geoffroy, 1810)}

Esta espécie hematófaga foi encontrada em 18 (90\%) das cavernas estudadas no Distrito Federal e Goiás: Gruta Morro, Gruta do Sal, Gruta Fenda II, Gruta da Saúva, Gruta Dança dos Vampiros, Gruta Dois Irmãos, Gruta Água Rasa, Gruta da Barriguda, Toca da Gameleira, Gruta Labirinto da Lama, Gruta Volks Clube, Gruta dos Morcegos, Toca do Falcão, Gruta Mogi, Toca Mata da Anta, Gruta Boca do Lobo, Gruta das Orquídeas e Fenda do Barreiro. As três últimas cavidades abrigavam exclusivamente colônias desta espécie; porém, a Fenda do Barreiro parece ter um trânsito noturno intenso de morcegos, pois quatro outras espécies foram capturadas somente enquanto adentravam-na no início da noite.

Alguns agrupamentos de $D$. rotundus continham poucos indivíduos ( 2 a 20); porém, a maioria era formada de 30 a 80 indivíduos, um intervalo de tamanho que GREENHALL et al. (1983) consideram como habitual (20 a 100 indivíduos) para esta espécie. Em Mambai, Goiás, foi observado que esta espécie formava agrupamentos de 10 a 15 indivíduos (CoimBra et al. 1982). No presente estudo, encontramos algumas colônias grandes que apresentavam de 100 a 300 indivíduos, principalmente naquelas cavidades que abrigavam somente $D$. rotundus. TRAJANO (1985) mencionou colônias com quantidades próximas ou maiores nas cavernas de arenito do estado de São Paulo. Em Yucatán, México, ARITA \& VARGAS (1995) encontraram uma colônia contendo mais de 1.000 indivíduos. Colônias maiores, com até 5.000 morcegos, também já foram mencionadas na literatura (ver GREENHALL et al. 1983). Segundo TADDEI (1983), esta espécie é altamente lucífuga e procura se abrigar nos locais mais escuros das cavernas. CoIMBRA et al. (1982) encontraram colônias situadas somente em locais mais profundos das grutas de Mambaí (áreas mais escuras). No presente estudo, $D$. rotundus mostrou-se mais versátil quanto à sua localização no interior das cavernas e suas colônias foram encontradas em fendas nas paredes e tetos ou pequenas reentrâncias próximas à entrada, e, também, em condutos ou salões situados mais internamente.

Observamos, em três cavernas (Gruta Mogi, Gruta Boca do Lobo e Fenda do Barreiro), grande acúmulo de fezes (poças) e um forte odor de amônia, indicando a presença de colônias relativamente grandes e/ou o uso prolongado desses abrigos por hematófagos (D. rotundus). Essas poças situavam se tanto próximas à entrada como nos salões mais internos nas cavernas.

Nas cavernas do Alto Ribeira, TRAJANo (1985) encontrou basicamente agrupamentos pequenos constituídos de no máximo 10 indivíduos e atribuiu esse fato à grande disponibilidade de abrigos na região. A autora citou, como exceções, duas grutas relativamente isoladas das demais, como contendo centenas de exem- 
plares de $D$. rotundus. É possível também que a inexistência de grandes rebanhos de gado bovino na região do Alto Ribeira contribua para a ocorrência de agrupamentos relativamente pequenos deste morcego hematófago.

Na região de Corumbataí, estado de São Paulo, CAMPANHÃ \& FowleR (1993, 1995) estimaram que as colônias de morcegos hematófagos continham cerca 600 (cavernas Fazendão-Paredão) e 800 indivíduos (caverna Cachoeira). Segundo os autores acima, foi estimado o tamanho da população de $D$. rotundus residente na caverna (ao nosso ver, foi estimado o tamanho da colônia). A presença dessas grandes colônias pode ser devido ao fato das cavernas estarem situadas em área de proteção ambiental (aparentemente não afetadas pelo programa de controle de morcegos hematófagos) e a existência de criações de gado bovino nas fazendas vizinhas. No Distrito Federal, a atividade produtiva predominante é a pecuária mista, de corte e de leite, com um rebanho de 124.000 cabeças em 1995. Em um estudo sobre os tipos de presa utilizados por D. rotundus do Distrito Federal, CARDOSO (1995) verificou que bovinos são suas principais presas. Desse modo, a oferta de alimento e de abrigos deve ter favorecido a formação de grandes agrupamentos desta espécie, tornando-a mais abundante e freqüente nas cavernas da região do Distrito Federal. Além disso, a ausência de um adequado programa de atividades de controle de morcegos hematófagos por parte dos órgãos oficiais deve ter contribuído para o aumento de suas populações.

Desmodus rotundus provavelmente se reproduz ao longo do ano, pois fêmeas grávidas foram observadas em todos os meses do ano, exceto em dezembro. Fêmeas com filhotes foram observadas em março, maio, julho e outubro. Nossos dados concordam com o padrão poliestro contínuo sugerido para $D$. rotundus por WILSON (1979) e Trajano (1985). Por outro lado, SchmidT (1988) menciona que esta espécie pode apresentar picos de nascimento de filhotes em diferentes épocas do ano, indicando uma atividade sexual sincronizada.

Na Toca do Falcão foram capturados apenas indivíduos machos de $D$. rotundus, em abril, agosto e novembro de 1993. Isto sugere a existência de segregação sexual com a formação de agrupamentos de machos solteiros, típicos da organização social em haréns (ver WILKINSON 1988). Próximo a esta cavidade, localiza-se a Fenda do Barreiro, que abrigava uma grande colônia de $D$. rotundus (cerca 300 indivíduos) de ambos os sexos. Situação semelhante foi observada na Gruta Volks Clube, onde somente indivíduos machos foram capturados, enquanto nas proximidades estava a Toca da Mata da Anta, onde existiam indivíduos de ambos os sexos. A coleta de exemplares machos somente ocorreu também na Gruta dos Morcegos; todavia, não encontramos outros agrupamentos desta espécie nas proximidades.

Desmodus rotundus foi observado nas cavernas da região do Distrito Federal em todos os meses do ano e coabitou com todas as outras espécies de morcegos (Tab. II).

\section{Glossophaga soricina (Pallas, 1766)}

Espécie nectarívora-onívora muito comum nas cavernas da região do Distrito Federal, sendo encontrada como residente em 15 (75\%) dos abrigos estudados: Gruta Morro, Gruta do Sal, Gruta Fenda II, Gruta da Saúva, Gruta Dança dos 
Vampiros, Gruta Dois Irmãos, Gruta Agua Rasa, Gruta da Barriguda, Toca da Gameleira, Gruta Labirinto da Lama, Gruta Volks Clube, Gruta dos Morcegos, Gruta Kipreste, Gruta Muralha e Toca Mata da Anta. Em quatro outras cavidades (Toca do Falcão, Gruta Mogi, Gruta das Orquídeas e Fenda do Barreiro), G. soricina foi capturada somente enquanto adentrava-as. Nossos dados discordam do comentário feito por TRAJANO (1995) que considerou esta espécie como um habitante de caverna relativamente raro. É possível que, em certas regiões brasileiras, $G$. soricina esteja abandonando áreas rurais e se deslocando para ambientes urbanos, onde parece ser muito comum. Na região metropolitana de São Paulo, G. soricina é a espécie de filostomídeo mais freqüente provavelmente por causa da grande oferta de abrigos (sotãos e porões), oferecidos pelas construções urbanas, e de alimento, fornecido pelas plantas da arborização de ruas (Silva et al. 1996). No Distrito Federal, nossos dados indicam sua presença constante nas cavernas e aparentemente não estaria se deslocando para os ambientes urbanos. BREDT \& UIEDA (1996) comentaram que a ocorrência pouco freqüente de G. soricina nas áreas urbanas do Distrito Federal poderia ser explicada pela escassa disponibilidade de abrigos urbanos (prédios urbanos de Brasília que apresentam sótãos e porões não são freqüentes), apesar da oferta relativamente alta de alimento, proporcionada pelas diversas espécies de plantas usadas na arborização (ver RODRIGUES et al. 1994).

Glossophaga soricina abriga-se normalmente nos espaços mais amplos (salões e amplas galerias), nas proximidades da entrada das cavidades. Observamos agrupamentos constituídos de, no máximo, 20 indivíduos, que parecem dividir o mesmo espaço com $C$. perspicillata e $L$. dekeyseri nas cavernas onde tais espécies coabitavam. Por outro lado, o mesmo parece não ocorrer nos abrigos em que $G$. soricina coabitava com A.geoffroyi, onde ambas formavam agrupamentos isolados. No nordeste do Brasil, WiLLIG (1983) encontrou colônias de G. soricina contendo mais de 2.000 indivíduos em cavernas e casas abandonadas. A formação de grandes colônias parece não ocorrer na região do Distrito Federal.

No presente estudo, encontramos fêmeas grávidas em setembro, outubro e dezembro e, em menor escala, em abril, maio e agosto. Fêmeas com filhotes e indivíduos jovens foram observados em junho, agosto e dezembro. Em Trinidad e Tobago, Goodwin \& GREENHALl (1961) registraram a ocorrência de fêmeas grávidas em janeiro, abril, maio, junho e dezembro, e de fêmeas lactantes em janeiro, fevereiro, março e junho e, ainda, de fềmeas com filhotes, em janeiro, março e junho. Na Colômbia, ARATA \& VAUGHAN (1970) capturaram 56\% das fêmeas grávidas em julho. WiLSON (1979) encontrou fêmeas grávidas em todos os meses do ano, sugerindo que esta espécie apresenta um ciclo de poliestria na maioria das áreas de ocorrência. No Brasil, Willig (1985) relatou a ocorrência de poliestria bimodal para esta espécie. Os dados obtidos na região do Distrito Federal concordam com o relato feito pelo autor acima.

Assim como D. rotundus, G. soricina foi observada em todos os meses do ano, mostrando ser uma espécie constante na região do Distrito Federal, onde coabitou cavernas com todas as outras espécies residentes (Tab. II). A coabitação entre $G$. soricina e $C$. perspicillata, que dividem o mesmo local no interior das cavernas, pode trazer benefícios mútuos, como redução dos custos metabólicos de 
termorregulação (GRAHAM 1988). No leste do Peru, estas duas espécies dividiram o mesmo espaço interno em pelo menos três tipos de abrigos (pequenas e grandes cavernas e construções) e, segundo GRAHAM (1988), esta relação não seria meramente convergência por necessidades dos mesmos recursos. $\mathrm{O}$ fato destas duas espécies dividirem o mesmo local dentro das cavernas merece mais atenção pois esta convivência está ocorrendo em ambientes relativamente quentes, não havendo necessidade aparente por parte dos morcegos de termorregular (E. Trajano, comunicação pessoal). De fato, a convivência entre ambas espécies foi também registrada em duas outras regiões quentes, uma no Espírito Santo (W.A. Pedro, comunicação pessoal) e outra no estado da Bahia (W. Uieda, dados não publicados).

\section{Carollia perspicillata (Linnaeus, 1758)}

Espécie frugívora comum e encontrada como residente em $8(40 \%)$ das cavernas estudadas: Gruta Morro, Gruta do Sal, Gruta Fenda II, Gruta da Saúva, Gruta Dança dos Vampiros, Gruta Dois Irmãos, Toca da Gameleira e Toca do Falcão; e em seis outras, como não-residente: Gruta Água Rasa, Gruta da Barriguda, Gruta Labirinto da Lama, Gruta Volks Clube, Gruta Mogi e Fenda do Barreiro. Esta espécie é comum em diversas áreas da região neotropical, onde utiliza diversos tipos de abrigo, como cavernas, bueiros e construções. Contudo, ARITA \& VARGAS (1995) verificaram que $C$. perspicillata é rara nas cavernas de Yucatán (México), não apresentando uma explicação para este fato.

Os agrupamentos de $C$. perspicillata foram encontrados abrigando-se normalmente no teto dos salões e galerias situadas próximo à entrada das cavidades, onde dividiam esse espaço com $G$. soricina e $L$. dekeyseri, quando em coabitação. Em tais locais, os indivíduos das três espécies permaneciam pendurados com o auxílio dos pés, isoladamente ou em pequenos grupos ( 2 a 6 indivíduos sem contato corporal). Somente na Gruta Morro (abril/93), observamos uma colônia de aproximadamente 40 a 50 indivíduos, em contato corporal, formando verdadeiro "cacho", em um conduto à entrada da cavidade. Quando perturbados, estes morcegos voavam de um lado para outro e pousavam novamente no teto; porém, sem restabelecer imediatamente o contato corporal. Segundo NowAK (1991), indivíduos desta espécie podem ser encontrados nos abrigos, isoladamente, em pequenos grupos, ou ainda constituir colônias de centenas ou milhares de indivíduos. Para Cloutier \& THOMAS (1992), seus agrupamentos conteriam geralmente de 10 a 100 indivíduos. Isto parece acontecer também na região do Distrito Federal. Nas cavernas de Corumbataí, São Paulo, os agrupamentos de C. perspicillata eram pequenos e continham de 5 a 10 indivíduos (CAMPANHÃ \& FOWLER 1993).

No presente estudo, examinamos fêmeas em todos os meses do ano e a ocorrência de gravidez foi detectada nos meses de fevereiro, abril, agosto, setembro, outubro, novembro e dezembro. Por outro lado, fềmeas com filhote foram observadas somente em fevereiro e em outubro. WILSON (1979) e TRAJANO (1985) sugerem um padrão reprodutivo bimodal para $C$. perspicillata. Nossos dados indicam esse mesmo padrão no Distrito Federal. Estudos desenvolvidos na Costa Rica e no Panamá sugerem que os dois picos de reprodução desta espécie coincidem com a produção local de frutos (CLOUTIER \& THOMAS 1992). Não temos dados similares para a região do Distrito Federal. 
GoOdWIN \& GREENHALL (1961) encontraram abrigos contendo somente indivíduos machos em janeiro, fevereiro e junho, e outros abrigos contendo fêmeas com filhotes em janeiro, abril e outubro. Nossos dados não sugerem a ocorrência de segregação sexual em C. perspicillata do Distrito Federal.

Assim como as duas outras espécies comuns anteriormente citadas, $C$ perspicillata foi observada em todos os meses do ano, e coabitou com outras 15 espécies residentes nas cavernas do Distrito Federal (Tab. II).

\section{Mimon bennettii (Gray, 1838)}

Esta espécie insetívora foi encontrada em seis $(30 \%)$ cavernas do Distrito Federal e Goiás: Gruta Morro, Gruta do Sal, Gruta Fenda II, Gruta da Saúva, Gruta Dois Irmãos e Gruta da Barriguda. Essas cavernas caracterizam-se por abrigar uma alta riqueza de espécies, com uma média de 7,0, bem acima da média encontrada no presente estudo $(4,4)$. Não temos uma explicação plausível para este fato.

$\mathrm{Na}$ Gruta Dois Irmãos, observamos três indivíduos pousados na parede vertical do conduto inferior da cavidade. $\mathrm{Na}$ Gruta da Saúva, dois indivíduos foram vistos, por duas vezes consecutivas e no mesmo conduto, pendurados no teto baixo de $0,5 \mathrm{~m}$ a $2 \mathrm{~m}$ de altura do solo. Estes morcegos permaneciam pendurados pelos pés e sem contato corporal entre si. Em agosto de 1992, encontramos três indivíduos (um macho e duas fềmeas, grávidas) no salão de entrada de uma pequena toca situada no topo de um morro. Pequenos agrupamentos (dois a quatro indivíduos) de $M$. bennettii parecem ser o tamanho habitual de suas colônias (NowAK 1991) e nossos dados concordam com essa informação. Efetivamente, ORTEGA \& ARITA (1997) comentam que esta espécie forma colônias contendo menos de 10 indivíduos.

Fêmeas grávidas foram encontradas nos meses de março, agosto, setembro e outubro. No sul do México e na América Central foram registradas fêmeas grávidas e lactantes de março a agosto (NoWAK 1991). O nascimento dos filhotes ocorre no início da estação chuvosa (WILSON 1979).

Essa espécie foi registrada nas cavernas do Distrito Federal em todos os meses do ano, exceto junho. É classificada como uma espécie segregacionista pois geralmente coabita cavernas com poucas espécies (ORTEGA \& ARITA 1997). No presente estudo, M. bennettii coabitou as cavernas do Distrito Federal com 12 outras espécies (Tab. II); contudo, nunca a observamos dividindo o mesmo espaço no interior dos abrigos com outras espécies.

\section{Peropteryx macrotis (Wagner, 1843)}

A freqüência de ocorrência desta espécie insetívora foi também de $30 \%$ das cavernas estudadas do Distrito Federal: Gruta do Sal, Gruta Dois Irmãos, Gruta da Barriguda, Toca da Gameleira, Gruta Labirinto da Lama e Gruta Kipreste. Normalmente $P$. macrotis foi observado pousado nas paredes, nas fendas e no teto dos condutos amplos (zona de penumbra), próximas à entrada das cavidades. Esses dados concordam com os obtidos por TrAJANO $(1985,1996)$ para esta espécie no Alto Ribeira. Peropteryx macrotis adota a postura de contato, de cabeça para baixo, apoiando os polegares no substrato, e sem contato corporal com outros membros da 
colônia. Tal comportamento parece ser característico desta espécie, tendo já sido descrito anteriormente por TRAJANO (1985). Nas cavernas do Distrito Federal, identificamos uma vocalização característica, tipo "chiado", que facilitava a localização destes animais no interior dos abrigos diurnos. Quando perturbados, $P$. macrotis voava adentrando as frestas das paredes próximas. Segundo EISENBERG (1989), suas colônias são geralmente pequenas, variando de um a sete indivíduos. WILLIG (1983) observou, no nordeste brasileiro, agrupamentos com mais de 10 morcegos contendo apenas um macho, o que sugere que machos de $P$. macrotis mantém pequenos haréns.

No presente estudo, poucos dados foram obtidos sobre sua reprodução. Uma fêmea grávida foi capturada em setembro e outra, carregando um filhote, em outubro. No Alto Ribeira, TRAJANO (1985) encontrou fêmeas lactantes e/ou filhotes nos meses de dezembro e janeiro. Baseando-se em seus dados e nos de literatura, esta autora sugeriu um ciclo reprodutivo do tipo monoestro sazonal para P. macrotis, com um pico de nascimento entre o fim da estação seca e o início da chuvosa. Nossos dados concordam com esta sugestão.

No Distrito Federal, essa espécie foi observada nos meses de janeiro, março, maio, junho, setembro, outubro e novembro e coabitou com outras 10 espécies de morcegos (Tab. II).

\section{Diphylla ecaudata Spix, 1823}

Esta espécie hematófaga foi encontrada, como residente, em 5 (25\%) cavernas estudadas: Gruta Morro, Gruta do Sal, Gruta Fenda II, Gruta da Saúva e Toca da Gameleira; e, como não-residente, em duas: Gruta Mogi e Gruta das Orquídeas. ARITA \& VARGAS (1995) consideram essa espécie como pouco comum na região de Yucatán, México, tendo sido encontrada em somente $17 \%$ das cavernas por eles estudadas. Diphylla ecaudata é menos gregária que D. rotundus e, de modo geral, forma agrupamentos de um a três indivíduos ou até de 12 indivíduos (GREENHALL et al. 1984; NowAK 1991). Porém, há três registros sobre a ocorrência de colônias relativamente grandes: de 25 a 35 indivíduos em Yucatán (ARITA \& VARGAS 1995) e de cerca 50 indivíduos nos estados do Rio de Janeiro e de São Paulo (PICCININI \& AQUINO 1979; W. Uieda, dados não publicados). Em Goiás, observamos colônias de cerca 40 indivíduos na Gruta Primavera (GO 025) e 24 na Gruta Córrego Saracura (GO 171). O maior agrupamento na região do Distrito Federal foi observada na Gruta da Saúva, onde, em uma ocasião, capturamos 17 indivíduos (13 fêmeas e 4 machos). Na Gruta Morro, acompanhamos, aparentemente, o processo de sua ocupação por D. ecaudata e a formação de sua colônia. Entre 1991 e 1994, havíamos coletado sempre um indivíduo macho; porém, em 1995, capturamos um grupo de 13 morcegos (8 machos e 5 fêmeas). Em novembro de 1996, A. Bredt observou uma colônia contendo 12 indivíduos jovens e adultos de ambos os sexos (Fig. 4). Nas demais cavernas, foram encontrados apenas indivíduos solitários (geralmente machos). Em Apiaí, estado de São Paulo, W. Uieda capturou, em 1988, quatro machos solteiros em uma mina abandonada (os únicos indivíduos existentes nesse abrigo). Dois anos depois, havia nesse abrigo uma colônia de pelo menos 50 indivíduos, de ambos os sexos. É possível que a colonização de abrigos por $D$. ecaudata seja 
iniciada por um ou poucos indivíduos machos. Se essa suposição for verdadeira, os vários agrupamentos de um a três indivíduos desta espécie, citados na literatura, são de machos à espera de fêmeas para formar novas colônias.

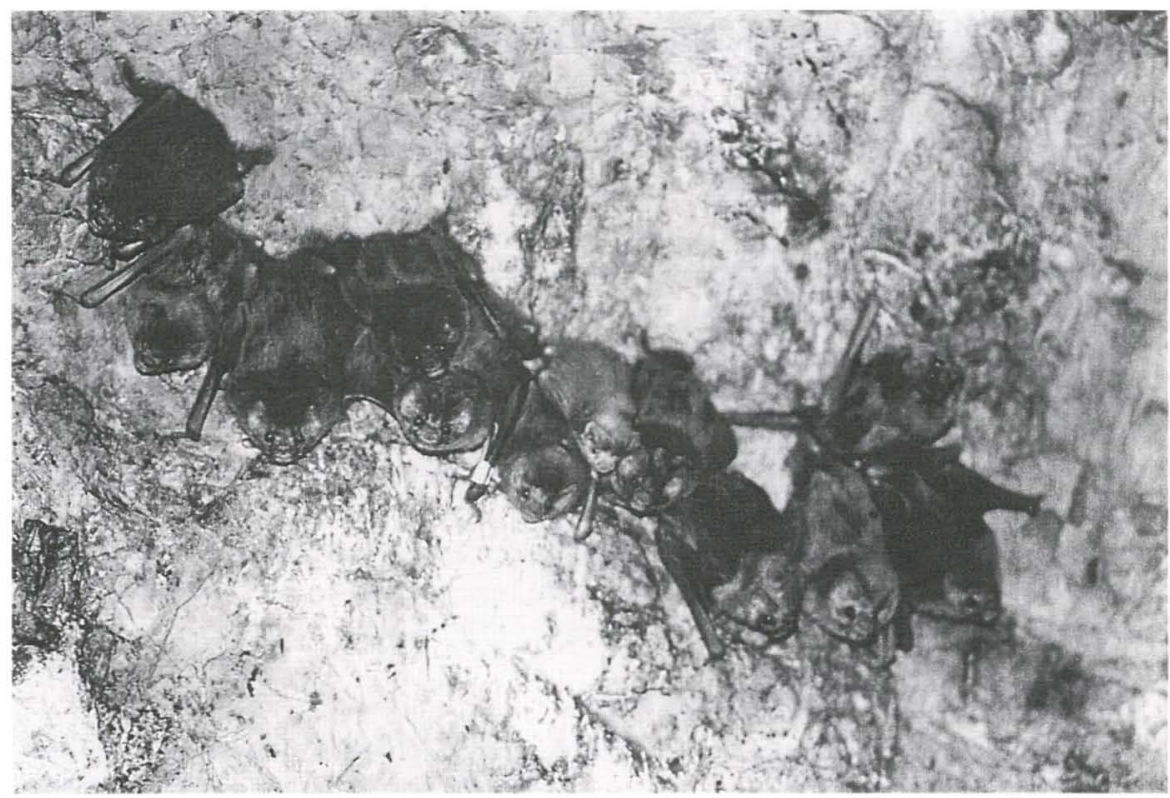

Fig. 4. Colônia de 12 individuos de Diphylla ecaudata observados enquanto pousados no teto da Gruta Morro, em novembro de 1996. Note que há um individuo adulto anilhado e, pelo menos, três filhotes. (Foto: A. Bredt).

Nos abrigos, os exemplares de $D$. ecaudata foram localizados habitualmente pousados no teto dos salões e condutos com dois a três metros de altura, não distantes da entrada. Quando iluminados os morcegos permaneciam imóveis, podendo ser facilmente capturados com auxílio de puçás ou mesmo com a mão. Após a perturbação inicial, os morcegos tornavam-se ariscos, voavam para outros salões ou galerias, onde pousavam no teto e não permitiam nova aproximação. Nunca observamos esta espécie escondendo-se em fendas das paredes verticais e dos tetos como D. rotundus, concordando com a descrição do comportamento de $D$. ecaudata feita por GREENHALL et al. 1984. Diphylla ecaudata alimenta-se principalmente em aves (GARDNER 1977; GreEHNALL et al. 1984; GREENHALL 1988; NowAK 1991) e, no Distrito Federal, esta espécie parece efetivamente estar explorando aves (galinhas), pois capturamos alguns exemplares em redes armadas junto às árvores que serviam de poleiro para aves. Além disso, temos relatos locais de ocorrência de bicheira (ver BREDT et al. 1996) na região da cloaca de diversas galinhas, local freqüentemente sangrado por $D$. ecaudata. Segundo BREDT et al. (1996), as mordeduras provocadas pelos morcegos servem como locais para alojamento de larvas de moscas varejeiras, que podem até provocar a morte das aves. 
Fêmeas grávidas foram observadas nos meses de fevereiro, março, julho, setembro e outubro. Em setembro de 1992, das cinco fêmeas capturadas, três estavam grávidas e uma carregava seu filhote. Em fevereiro de 1995, na Gruta Morro encontramos uma fêmea grávida, quatro não-gravidas, três machos escrotados, quatro com testículos abdominais e um juvenil. Em dezembro do mesmo ano, capturamos, nesta mesma gruta, três machos adultos e quatro fêmeas (duas juvenis e duas adultas). Na Gruta Primavera (Goiás), dos quatro morcegos capturados em agosto de 1993, dois eram machos e duas fêmeas carregavam seus filhotes-machos (A. Bredt, dados não publicados). No Alto Ribeira, TRAJANO (1985) coletou fêmeas grávidas em janeiro e fevereiro e lactantes em dezembro e março (meses em que foi possível capturar fêmeas). Segundo esta autora, os dados poderiam indicar que o nascimento dos filhotes ocorreria no segundo semestre, no início do período das chuvas. No México e na América Central, fêmeas grávidas e lactantes foram encontradas em março, maio, julho, agosto, outubro e novembro (WILSON 1979). É possível que $D$. ecaudata tenha um padrão reprodutivo poliestro contínuo, como D. rotundus, ou, pelo menos, dois períodos de reprodução ao longo do ano, como sugerido por WILSON (1979).

Apesar de não ser uma espécie abundante, $D$. ecaudata foi freqüente no Distrito Federal, sendo observada em quase todos os meses do ano, e dividiu as cavernas com outras 12 espécies de morcegos (Tab. II).

\section{Phyllostomus hastatus (Pallas, 1767)}

Esta espécie onívora foi encontrada em 5 (25\%) das cavidades naturais estudadas na região do Distrito Federal: Gruta Morro, Gruta do Sal, Gruta Dois Irmãos, Gruta Agua Rasa e Gruta da Barriguda. Assim como os abrigos de $M$. bennettii, os de $P$. hastatus possuiam também uma alta riqueza de espécies (média de 7,0). A maior colônia de $P$. hastatus (cerca 80 indivíduos) foi observada na Gruta Água Rasa, abrigando-se numa pequena concavidade na parte mais ampla da caverna. Os morcegos mantinham um estreito contato corporal entre si, aparentando ser um harém (ver descrição em MCCRACKEN \& BRADBURY 1981). A maioria dos indivíduos saia para sua atividade noturna, entre 18:00 e 19:00 h. Na Gruta Morro, encontramos, na mesma colônia, indivíduos com pelagem alaranjada e outros com pelagem castanho-escura. A ocorrência de polimorfismo quanto à pelagem em $P$. hastatus é um fenômeno já conhecido na literatura (ALLEN 1939).

Fêmeas grávidas foram observadas em junho, agosto e outubro. Em Trinidad, MCCRACKEN \& BRADBURY (1981) observaram que a atividade sexual de $P$. hastatus ocorria de outubro a fevereiro e havia um período sincronizado de nascimento dos filhotes nos meses de abril e maio.

Apesar desta espécie ter sido registrada em poucas cavernas do Distrito Federal, foi observada nas mesmas em todos os meses do ano, exceto janeiro e março. Nesses abrigos, coabitou com 15 outras espécies de morcegos (Tab. II).

\section{Anoura geoffroyi Gray, 1838}

Espécie nectarívora não comum nas cavernas do Distrito Federal, tendo sido registrada em apenas quatro (20\%) das cavernas estudadas: Gruta Dança dos 
Vampiros, Gruta Agua Rasa, Gruta Volks Clube e Gruta dos Morcegos. Uma característica geral dessas quatro grutas é a presença de curso d'água em seu interior, a semelhança do observado nas cavernas do Alto Ribeira onde essa espécie foi também encontrada (TRAJANO 1985). Apesar de pouco freqüente, suas colônias eram constituídas de muitos indivíduos (100 a 300) que se abrigavam no teto dos salões mais amplos, entre a zona de penumbra e de escuridão. Nas áreas rurais do Distrito Federal, esta espécie tem sido observada também em bueiros sob ferrovias percorridos temporariamente por cursos de águas pluviais. A existência de grandes colônias de $A$. geoffroyi na região estudada parece não ser um fato isolado na natureza, pois já havia sido registrado por TRAJANO (1985) e NOWAK (1991). A primeira autora mencionou a ocorrência de uma colônia em uma das cavernas do Alto Ribeira, contendo várias centenas (ou talvez mais de um milhar) de exemplares desta espécie. Anoura geoffroyi parece ser uma espécie comum, mas de distribuição muito restrita (TRAJANO 1985). Nas colônias, os morcegos penduravam-se no substrato com auxílio dos pés e não mantinham contato corporal, um comportamento de repouso semelhante ao exibido por $G$. soricina e $L$. dekeyseri.

Fêmeas grávidas foram capturadas em maio e outubro; fêmeas lactantes e carregando filhotes, em maio, e fêmeas grávidas e lactantes, em junho. Em julho de 1992, na Gruta Dança dos Vampiros foram capturados somente indivíduos machos (38), todos com os testículos escrotados, sugerindo atividade sexual. Cerca de três meses depois (outubro), foram capturados na mesma gruta 34 exemplares machos e 25 fêmeas, estando $12 \%$ delas grávidas. Isto sugere a ocorrência de segregação sexual temporal nesta espécie, com fêmeas se deslocando entre os abrigos. Em um estudo desenvolvido numa caverna do Distrito Federal, BAUMGARTEN \& VIEIRA (1994) mostraram que os machos abandonavam a caverna no período em que as fêmeas encontravam-se grávidas ou carregando filhotes e retornavam ao final do período de lactação. WILSON (1979) também sugeriu a ocorrência de segregação sexual em certas épocas do ano em $A$. geoffroyi de Trinidad. Nossos dados indicam a inexistência de uma época definida de reprodução para esta espécie no Distrito Federal. Por outro lado, BAUMGARTEN \& VIEIRA (1994) verificaram que o pico de nascimento dos filhotes (no início da estação seca) e o período em que os jovens começam a voar sozinhos estavam sincronizados com o período de floração de duas espécies de Pseudobombax. Segundo os autores acima, essa sincronização aumentaria a disponibilidade de recursos alimentares às fêmeas em lactação e aos jovens.

Nas cavernas do Distrito Federal, esta espécie foi registrada nos meses de fevereiro, março, maio, junho, julho, agosto e outubro e coabitou com nove outras espécies de morcegos (Tab. II).

\section{Furipterus horrens (F. Cuvier, 1828)}

Esta espécie insetívora não é comum e foi registrada em quatro $(20 \%)$ cavidades estudadas do Distrito Federal: Gruta Água Rasa, Toca da Gameleira, Gruta Mogi e Gruta Muralha. Com exceção da primeira, todas as outras cavernas são pequenas, não ultrapassando $34 \mathrm{~m}$ de desenvolvimento. $O$ tamanho das colônias de $F$. horrens variou de 20 a 80 indivíduos de ambos os sexos. No Ceará, UIEDA et al. (1980) encontraram colônias maiores, contendo 250 indivíduos na Gruta de 
Ubajara e 150, na Gruta de Araticum. Nesses dois abrigos, os indivíduos de $F$. horrens formavam pequenos agrupamentos ( 4 a 6 exemplares) ou grupos maiores (cerca 30 morcegos) alojavados em depressões mais ou menos profundas existentes nas paredes laterais e no teto dos salões e galerias. Nos grupos, os morcegos não mantinham contato corporal entre si. Nossos dados sobre comportamento dos morcegos, tamanho e distribuição dos agrupamentos concordam com os obtidos por UiEDA et al. (1980). Em uma gruta de Mambaí, CoIMBRA et al. (1982) observaram pequenos agrupamentos de $F$. horrens, que se distribuiam pelo interior da gruta. Exemplares desta espécie dificilmente são capturadas em redes-de-espera, tanto as armadas na entrada, como naquelas montadas no interior das cavernas (no presente estudo, apenas um exemplar foi capturado por esse método). Os morcegos em vôo desviavam-se das redes com extrema facilidade, sugerindo serem capazes de detectá-las sem dificuldades. É possível que isto seja responsável, em parte, pela sua relativa escassez em coleções científicas. A maior parte dos exemplares foi capturada em redes entomológicas, método também utilizado por UIEDA et al. (1980).

No Distrito Federal, fêmeas grávidas foram observadas em junho e outubro. Em outubro, além de $12 \%$ das fêmeas estarem grávidas, $41 \%$ outras estavam lactantes e carregavam seus filhotes em uma posição invertida, postura que foi descrita por UIEDA et al. (1980) como "de-cabeça-para-cima". Essa postura invertida decorre do fato do filhote permanecer agarrado às mamas funcionais, localizadas na região abdominal, logo acima da genitália (ver descrição detalhada em UIEDA et al. 1980). Esta relação entre mãe e filhote é conhecida somente em duas espécies: F. horrens (UIEDA et al. 1980) e Lavia frons (E. Geoffroy, 1810) (Megadermatidae) (VAUGHAN \& VAUGHAN 1987). Suspeita-se que deve também ocorrer na outra espécie de Furipteridae, Amorphochilus schnablii Peters, 1877 (UIEDA et al. 1980), que também possui mamilos funcionais abdominais (NOWAK 1991). Para a ocorrência da postura invertida do filhote, durante o descanso da mãe, não é necessária a presença de mamilos funcionais na região abdominal, pois $L$. frons os possui na região peitoral; porém, apresenta falsos mamilos na região inguinal (ver VAUGHAN \& VAUGHAN 1987).

Em uma gruta da Colômbia, CAMARGO \& TAMSITT (1990) capturaram cinco exemplares fêmeas de $F$. horrens, sendo uma grávida, três não-grávidas e uma jovem, em setembro. Os mesmos autores acreditam haver segregação sexual durante parte do ano. Na Costa Rica, LAVAL (1977) encontrou, em maio, mais de 59 machos em um oco-de-árvore caído. Na Guiana, machos solitários foram capturados numa caverna, em fevereiro (NOWAK 1991). No Ceará, UIEDA et al. (1980) encontraram em janeiro e fevereiro fêmeas com filhotes, estando a maioria deles em condições de voar. Apesar disso, os autores acreditavam que esses filhotes ainda estavam na fase lactente.

No Distrito Federal, observamos em uma noite de outubro de 1992 três filhotes (dois machos e uma fêmea) pendurados no teto do salão de entrada da Gruta Água Rasa, sem suas respectivas mães. Situação semelhante foi também observado por UIEDA et al. (1980) no Ceará. Os autores comentaram que as mães saem da gruta para a atividade noturna e não levam consigo os filhotes, que permanecem pousados no teto. Os filhotes devem representar uma carga extra e por isso, dificultaria os vôos de forrageamento desses insetívoros aéreos. 
Apesar de ocorrer em poucas cavernas do Distrito Federal (20\%), esta espécie foi registrada em vários meses do ano, exceto fevereiro, julho, novembro e dezembro. Nesses abrigos, coabitou com oito outras espécies de morcegos (Tab. II).

\section{Chrotopterus auritus (Peters, 1856)}

A freqüência de ocorrência desta espécie carnívora-insetívora nas cavernas do Distrito Federal foi de apenas 20\%, tendo sido encontrada na Gruta Dança dos Vampiros, Gruta da Barriguda, Gruta Labirinto da Lama e Gruta Volks Clube. Segundo Trajano (1995), é uma espécie comum em cavernas brasileiras, onde forma pequenos grupos. Em Yucatán, ARITA \& VARGAS (1995) suspeitaram que C. auritus utilizava cavernas apenas como um refúgio alternativo e não como abrigo diurno duradouro. Nas cavernas do Distrito Federal, nossos dados parecem indicar uma situação semelhante, pois seus agrupamentos foram encontrados uma única vez em cada uma das cavernas acima citadas. Nesses abrigos, C. auritus foi observada em pequenos grupos (dois a quatro) abrigando-se no teto próximo a entrada, estando habitualmente separados das demais espécies. O comportamento de formar pequenos grupos e se abrigar próximo à entrada da caverna parece ser habitual, tendo sido já observado por SAZIMA (1978), CoIMBRA et al. (1982), Trajano $(1985,1995,1996)$, CAMPANHÃ \& Fowler (1993) e ARITA \& VARGas (1995).

Poucos dados sobre reprodução foram obtidos no presente estudo. Apenas uma fêmea grávida foi capturada em outubro. Em São Paulo, TADDEI (1976) coletou fêmeas em atividade reprodutiva somente no segundo semestre do ano e TRAJANO (1985) encontrou uma fêmea grávida e lactante em dezembro. A referida autora argumentou que este fato indicaria poliestria em C. auritus do Alto Ribeira. Fêmeas grávidas foram encontradas em abril, no México, e em julho, na Argentina (MEDELLíN 1989). Machos com testículos escrotados foram observados em julho na Nicaragua e na Argentina (MEDELLín 1989).

Chrotopterus auritus foi observado nas cavernas nos meses de maio, julho e outubro. Embora seja encontrada com freqüência sozinha nas cavernas, pode coabitar com outras espécies (MEDELLín 1989). Este fato pode ser decorrência do seu hábito de atacar outras espécies de morcegos, um comportamento predatório já conhecido na literatura (MEDELLín 1989; UiEDA 1996). Fragmentos de ossos de morcegos foram encontrados no chão sob o abrigo de uma colônia desta espécie numa gruta situada próxima ao Distrito Federal (CoIMBRA et al. 1982). Em uma caverna de São Paulo, um indivíduo de $C$. auritus foi observado abocanhando e depois ingerindo um indivíduo de D. rotundus (UIEDA 1996). No presente estudo, C. auritus coabitou com outras nove espécies de morcegos do Distrito Federal (Tab. II).

\section{Lonchophylla dekeyseri Taddei; Vizotto \& Sazima, 1983}

Esta espécie nectarivora, pouco comum, foi registrada como residente em três $(15 \%)$ das cavidades naturais estudadas: Gruta Fenda II, Gruta da Saúva e Gruta Dois Irmãos; e, como não-residente em outras três: Gruta Morro, Gruta Dança dos Vampiros e Toca do Falcão. Em março de 1997, E. D. Magalhães observou esta 
espécie abrigando-se no teto do salão da Gruta Dança dos Vampiros; porém esse dado não foi considerado nas análises de freqüência de ocorrência desta espécie nas cavernas e de coabitação.

Lonchophylla dekeyseri foi descrita por TADDEI et al. (1983) com base em exemplares do Distrito Federal, da Serra do Cipó (Minas Gerais) e Piracuruca (Piauí). Outras citações desta espécie para o Distrito Federal foram feitas por MARINHO-FILHO (1996) e BREDT \& UIEDA (1996). O primeiro autor considera $L$. dekeyseri como uma espécie endêmica da região do cerrado e praticamente nada é conhecido sobre sua biologia. No presente estudo, esta espécie nunca foi observada em condutos profundos, restringindo-se principalmente aos primeiros salões, com dimensões mais amplas, onde dividia o espaço com G. soricina (Fig. 5). Os morcegos, de ambas a espécies, mantêm-se pendurados por um ou ambos os pés agarrando-se às asperezas do teto do salão e sem contato corporal com outros indivíduos. Uma interação aparentemente agonística foi observada entre dois indivíduos. O morcego pousado (aparentemente uma fêmea grávida) vocalizava em direção a outro (um macho) que se aproximava em vôo (Fig. 6). Esta observação foi feita entre 12:30 e 14:30 h do dia 23 de março de 1997 na gruta Dança dos Vampiros e seu significado é ainda desconhecido.

Fêmeas grávidas foram observadas nos meses de março, abril, maio e junho e fêmeas com filhotes nunca foram encontradas.

A captura de um total de mais de cem indivíduos em apenas três abrigos, em diversas ocasiões, sugere que suas colônias não são pequenas, talvez compostas por algumas poucas dezenas de indivíduos. Lonchophylla dekeyseri foi registrada em todos os meses, exceto julho, e coabitou com nove espécies (Tab. II).

\section{Pteronotus parnellii (Gray, 1843)}

Pteronotus parnellii foi encontrada somente em 2 (10\%) cavidades estudadas na região do Distrito Federal: Gruta Morro e Gruta Dança dos Vampiros. Apesar de ser uma espécie insetívora de hábitos gregários e que pode formar grandes colônias (CEBALlos-GoNZÁlez \& GALINDO-LEAL 1984; TRAJANO \& MOREIRA 1991), no Distrito Federal foram encontrados agrupamentos com menos de 100 morcegos. Na Gruta Morro, foram observados indivíduos no conduto próximo à entrada e ainda em um pequeno salão a $10 \mathrm{~m}$ da entrada, tendo sido capturados 12 indivíduos machos e somente uma fêmea. Na Gruta Dança dos Vampiros, foram coletados somente machos (25) em outubro de 1992, e machos (30) e fêmeas (22) em agosto de 1994. Em Trinidad e Tobago, essa espécie foi encontrada tanto em cavernas amplas quanto naquelas de menores dimensões (GOODWIN \& GREENHALL 1961). No México, esses morcegos abrigam-se principalmente em cavernas onde formam colônias contendo milhares de indivíduos (CEBALLOS-GonZÁLEZ \& GALINDO-LEAL 1984). No Brasil, TRAJANO \& MoREIRA (1991) encontraram colônias contendo de centenas a milhares de indivíduos em cavernas areníticas da região de Altamira, Pará, e comentaram que grandes populações de $P$. parnellii parecem caracterizar as cavernas amazônicas. Em Goiás, A. Bredt e E.D. Magalhães observaram duas colônias de 300 e 400 indivíduos, uma delas abrigada numa ampla cavidade de calcoxisto (Lapa Riacho Fundo - GO 190) e outra, numa gruta calcária de pequenas galerias (Gruta da Titara-GO 122). 


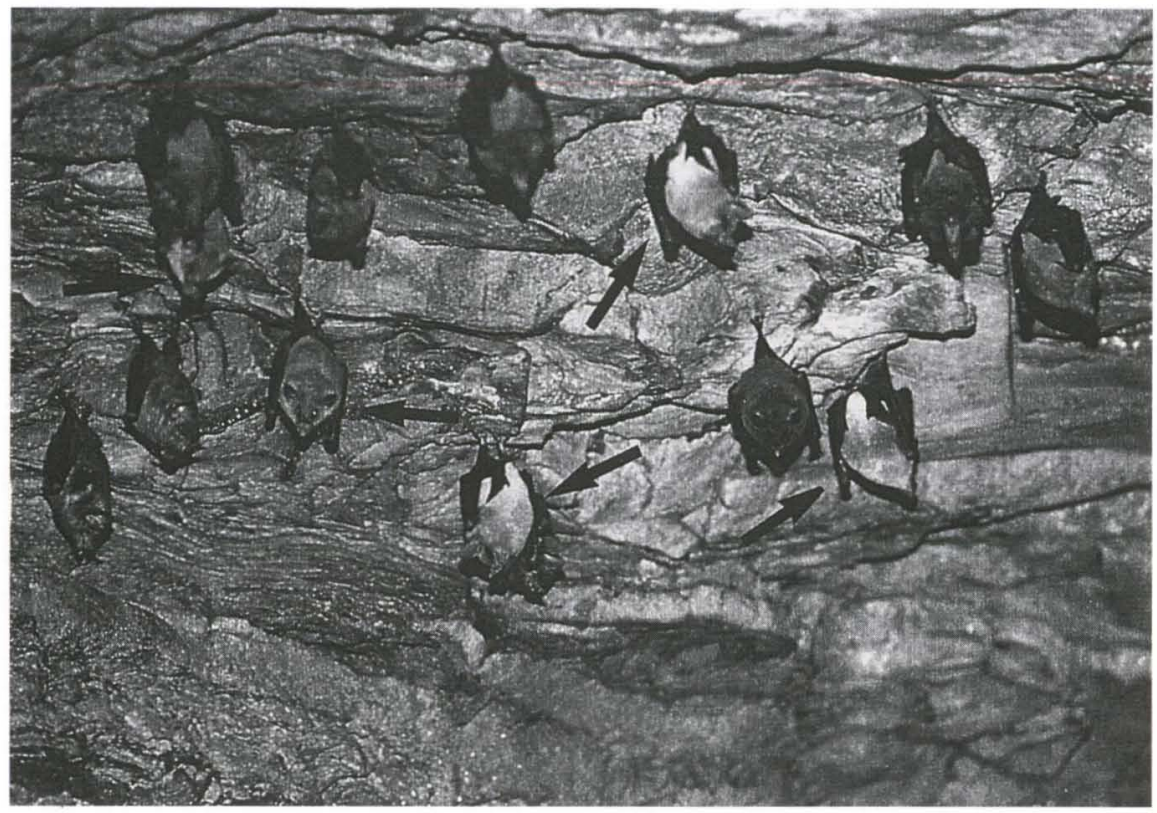

Fig. 5. Agrupamento contendo cinco indivíduos de Lonchophylla dekeyseri (castanho claro) (indicados pelas Setas) e nove de Glossophaga soricina (castanho escuro), observados na Gruta Dança dos Vampiros em março de 1997. (Foto: E.D. Magalhães).

Nas duas cavernas do Distrito Federal, encontramos indivíduos com pelagem castanho-escuro e com pelagem alaranjada. A ocorrência de polimorfismo quanto a cor da pelagem em $P$. parnellii já foi mencionada na literatura (ver HERD 1983).

Das 22 fêmeas capturadas em agosto na Gruta Dança dos Vampiros, 19 estavam grávidas. BATEMAN \& VAUGHAN (1974) encontraram a maioria das fêmeas grávidas em junho e lactantes em julho. EISENBERG (1989) comentou que, na Venezuela, o acasalamento ocorre em janeiro, quando ambos os sexos vivem no mesmo abrigo; já o nascimento dos filhotes ocorre em maio, quando existe maior abundância de insetos na região (HERD 1983). Após o período de copulação, indivíduos machos e fêmeas parecem segregar-se em diferentes abrigos (HERD 1983). No Distrito Federal, o acasalamento deve ocorrer entre julho e agosto e o nascimento dos filhotes, entre dezembro e janeiro, durante a estação chuvosa, período de maior ocorrência de insetos na região. Nosso dados indicam que a Gruta Morro é utilizada apenas como local de abrigo dos machos, enquanto a Gruta Dança dos Vampiros abrigaria indivíduos de ambos os sexos no período reprodutivo.

Pteronotus parnellii foi observada nas duas cavernas do Distrito Federal nos meses de abril, julho, agosto, outubro e dezembro, e coabitou com 11 outras espécies de morcegos, como mostrado na tabela II. 


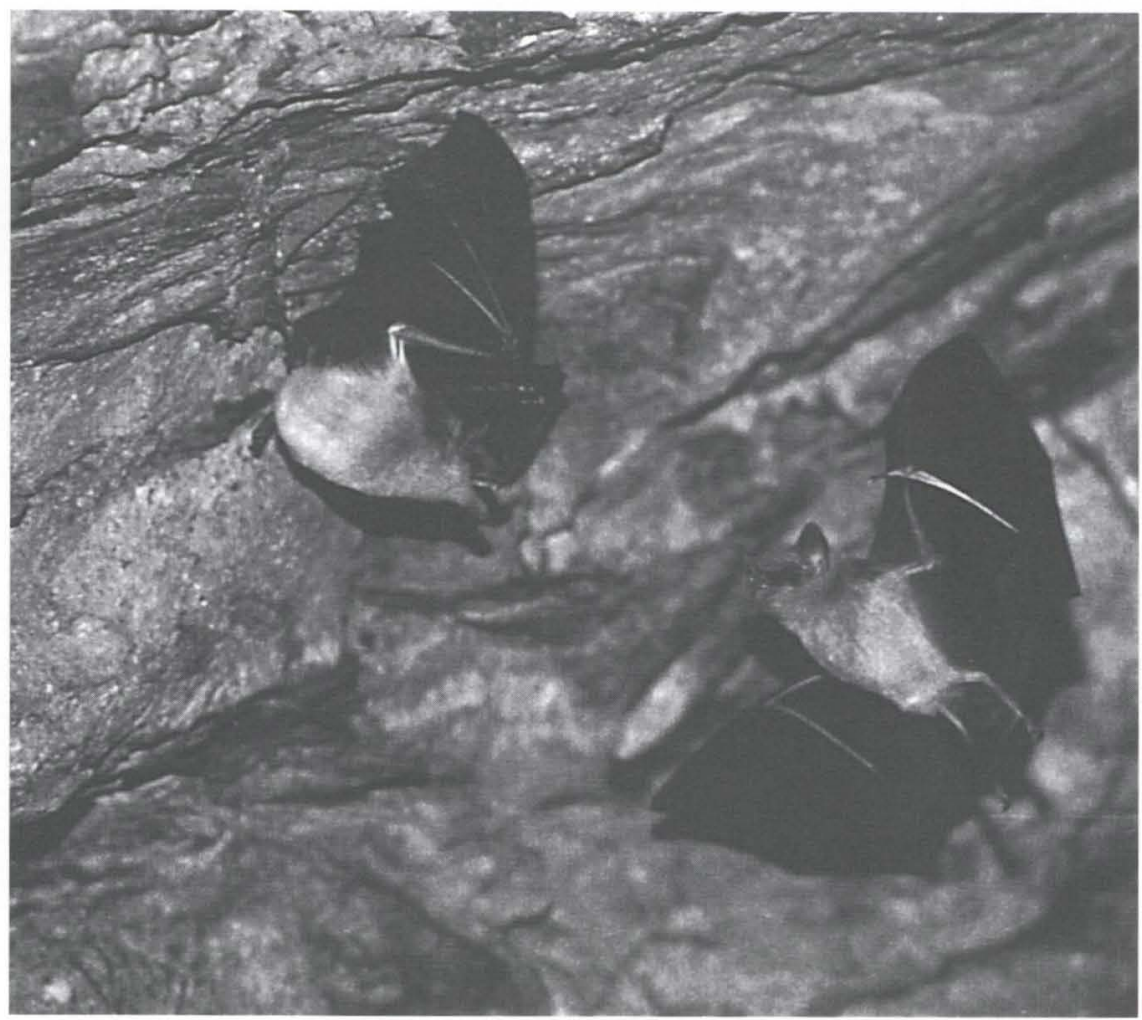

Fig. 6. Interação agonística entre dois indivíduos de Lonchophylla dekeyseri na Gruta Dança dos Vampiros, observada em março de 1997. O indivíduo pousado, aparentemente uma fêmea grávida (note seu abdome expandido), está com a boca aberta e vocalizando em direção a outro individuo (macho) que se aproximava em vôo. (Foto: E.D. Magalhães).

\section{Trachops cirrhosus (Spix, 1823)}

Esta espécie carnívora-insetívora foi registrada somente em duas (10\%) das cavidades do Distrito Federal: Gruta do Sal e Gruta Fenda II. Seus indivíduos nunca foram localizados no interior dessas cavidades, sendo capturados apenas nas redes, enquanto saiam para atividade noturna. Em janeiro de 1994, foram capturados na Gruta Fenda II três indivíduos machos, sendo dois adultos e um jovem. A ausência de observações de seus agrupamentos no interior das cavernas e a captura de poucos indivíduos sugerem a ocorrência de colônias reduzidas na região do Distrito Federal. Nossos dados indicam, ainda, que $T$. cirrhosus não é uma espécie comum na região. Por outro lado, no Alto Ribeira, TRAJANO (1985) encontrou, em fevereiro, em uma única gruta, uma colônia constituída de centenas de indivíduos, formando várias agrupamentos, a até quase um quilômetro da entrada. Esses agrupamentos (de $10 \mathrm{a}$ 20 indivíduos, em contato corporal) localizavam-se tanto na galeria principal como em fendas e galerias laterais, tanto mais internas como próximas à entrada da caverna (TRAJANO 1985). 
Não temos dados sobre a reprodução dessa espécie no Distrito Federal. No Alto Ribeira, TRAJANO (1985) encontrou fêmeas grávidas em outubro, uma lactante em dezembro e uma grávida e lactante em agosto, sugerindo um padrão reprodutivo poliestro, com dois picos anuais de nascimento, um anterior e o outro posterior a agosto. Em Trinidad e Tobago, GoodwIN \& GREENHALL (1961) encontraram uma colônia de $T$. cirrhosus composta de seis indivíduos de ambos os sexos, em um oco-de-árvore; duas fêmeas grávidas foram capturadas em março.

Trachops cirrhosus foi registrada nas duas cavernas do Distrito Federal nos meses de janeiro, março, junho, outubro e novembro, e coabitou com oito espécies (Tab. II).

\section{Micronycteris megalotis (Gray, 1842)}

A freqüência de ocorrência desta espécie insetívora em cavidades do Distrito Federal e Goiás foi de apenas $10 \%$, tendo sido capturada na Gruta Morro e na Gruta da Saúva. Não temos observações de M. megalotis abrigando-se no interior das mesmas; porém, três indivíduos foram capturados enquanto saíam entre 18:30 e 21:00 h. Em duas outras cavidades (Toca da Gameleira e Gruta Mogi), os morcegos foram coletados somente enquanto adentravam essas cavernas. $\mathrm{O}$ fato de poder abrigar-se solitariamente ou em pequenos grupos (FENTON \& KUNZ 1977) e de possuir porte pequeno podem ter dificultado a observação dessa espécie no interior das cavernas estudadas. ALONSO-MEJíA \& MEDELLÍN (1991) mencionaram que $M$. megalotis já foi encontrada se abrigando em ocos-de-árvore, pequenas cavernas, fendas em rochas, espaços sob pontes, túneis, construções e casas. No leste do Peru, GRAHAM (1988) encontrou esta espécie em ocos-de-árvore e pequenas cavernas. Em Corumbataí, CAMPANHÃ \& FOWLER (1993) capturaram-na somente em pequenas cavernas; porém, esses autores não especificaram os locais onde os morcegos abrigavam-se no interior desses abrigos. Em Trinidad e Tobago, esta espécie utiliza normalmente pequenas cavernas bem iluminadas e locais próximos às entradas das grandes cavernas (GoODWIN \& GREENHALL 1961).

$\mathrm{Na}$ Gruta Morro, o morcego capturado em agosto de 1992 era uma fêmea grávida. Na Toca da Gameleira, duas fêmeas foram capturadas em abril de 1992 e na Gruta Mogi, uma fêmea não-grávida em setembro de 1992. No Peru, na Bolívia e no Brasil, fêmeas grávidas foram registradas em fevereiro, março, junho, julho e agosto, e fêmeas lactantes, em junho, agosto e novembro (ALONSO-MEJía \& MEDELLín 1991). Em Trinidad e Tobago, foram observadas fêmeas grávidas em fevereiro e março e fêmeas lactantes, em junho (GoodwIN \& GREENHALL 1961). $\mathrm{Na}$ Costa Rica, foram registradas fêmeas grávidas em abril, fềmeas lactantes em maio, sub-adultas em agosto e setembro e não grávidas, de outubro a fevereiro (NOWAK 1991). No México, fêmeas grávidas foram encontradas em fevereiro, abril e maio e fêmeas lactantes, somente em maio (ALONSO-MEJía \& MEdELLín 1991).

Invidíduos de $M$. megalotis foram coletados em abril, agosto, setembro e novembro nas quatro cavernas acima mencionadas, onde co-ocorreu com nove outras espécies da região do Distrito Federal (Tab. II). 


\section{Lonchorhina aurita Tomes, 1863}

Esta espécie insetívora foi encontrada abrigando-se somente na Gruta Morro. Nesse abrigo diurno, os morcegos podiam ser observados pousados no teto e nas paredes do conduto próximo à entrada e também nas partes mais escuras desta cavidade. Foram observados saindo entre 18:40 e 19:10 h e retornando logo depois, a cerca de 19:40 h. Em duas outras cavidades (Gruta Dois Irmãos e Gruta Volks Clube), apenas um indivíduo macho foi capturado em rede enquanto adentrava a caverna. Em Trinidad e Tobago, GoodwIN \& GREENHALL (1961) observaram uma colônia de 20 a 25 indivíduos situada num teto elevado de uma caverna. No Panamá, um agrupamento com mais de 500 indivíduos, de ambos os sexos, foi encontrado em uma mina (EISENBERG 1989).

Pouco se conhece sobre os hábitos dessa espécie (GOODWIN \& GREENHALL 1961; LASSIEUR \& WILSON 1989). Todos os 44 indivíduos capturados no presente estudo eram machos. Considerando-se os quatro anos de estudos na Gruta Morro, com visitas em vários meses do ano, esta gruta parece ser utilizada apenas por indivíduos machos, indicando haver segregação sexual nessa caverna. Colônias desta espécie, contendo exemplares de ambos os sexos, foram encontradas em três cavernas do Alto Ribeira; contudo, agrupamentos com somente indivíduos machos foram também encontrados em outras três cavidades (E. Trajano, com. pessoal). Na literatura consultada, não há referência sobre segregação sexual em L. aurita e a ocorrência de ambos os sexos tem sido registrada nas colônias citadas na literatura (ver LASSIEUR \& WILSON 1989).

Não temos dados sobre reprodução de L. aurita. Segundo WILSON (1979), que se baseou em dados principalmente da América Central, fềmeas grávidas seriam encontradas no período seco (fevereiro a abril) e o nascimento dos filhotes coincidiria com o período chuvoso. Em uma caverna da Bahia, diversas fềmeas com filhotes foram capturadas no mês de novembro, início da estação chuvosa na região (W. Uieda, dados não publicados). Em Goiás, foram capturados cinco indivíduos (duas fêmeas e três filhotes, um macho e duas fềmeas) na Lapa Riacho Fundo (GO 190) que abrigava uma colônia de cerca 30 indivíduos (A. Bredt e E.D. Magalhães, dados não publicados).

Considerando-se todos os registros nas três cavernas onde foi capturada, $L$. aurita foi encontrada no Distrito Federal em fevereiro, abril, julho, agosto, setembro e dezembro. Na única caverna em que foi observada, coabitou com oito espécies (Tab. II).

\section{Pteronotus gymnonotus Natterer, 1843}

Apenas um indivíduo macho desta espécie insetívora foi capturado, em julho de 1992, na Gruta Dança dos Vampiros, junto com 25 exemplares machos de $P$. parnellii. Praticamente nada é conhecido sobre sua biologia e a captura de um único exemplar sugere que é uma espécie rara na região. Em Goiás, apenas um indivíduo, macho, de Pteronotus gymnonotus foi capturado nas diversas cavernas pesquisadas (A. Bredt e E.D. Magalhães, dados não publicados). Esta espécie parece ter preferência por cavernas amplas e úmidas (GoodwIN \& GREENHALL 1961; REDFORD. \& EISENBERG 1992) e coabita com diversas espécies, incluindo $P$. 
parnellii e várias espécies de filostomídeos (EISENBERG 1989). No leste do Peru, GraHAM (1988) observou P. gymnonotus apenas em uma grande caverna, onde coabitava com $P$. hastatus. No presente estudo, foi encontrada coabitando com seis espécies (Tab. II).

Não temos dados sobre sua reprodução; porém, NowAK (1991) mencionou que fêmeas grávidas foram capturadas em maio e junho, no México, e em abril e maio, na Nicarágua.

\section{Phylloderma stenops Peters, 1865}

Apenas um indivíduo desta espécie insetívora, uma fêmea grávida, foi capturada em julho de 1990 na Gruta Água Rasa. Esta espécie parece ser bastante rara pois há pouquíssimos exemplares em coleções e aparentemente tem preferência por cavernas como abrigo diurno. TRAJANO (1985) encontrou quatro indivíduos em uma caverna do Alto Ribeira e um exemplar em caverna do norte de Minas Gerais (E. Trajano, com. pessoal). Na Costa Rica, NowAK (1991) citou que uma fêmea grávida foi coletada em fevereiro.

Na região do Distrito Federal, $P$. stenops coabitou com apenas cinco espécies na única caverna em que foi registrada (Tab. II).

\section{Anoura caudifer (E. Geoffroy, 1818)}

Esta espécie nectarivora não foi registrada como residente nas cavernas estudadas. Por outro lado, 17 exemplares de A. caudifer foram capturadas, em 10 meses diferentes, adentrando seis cavidades (Gruta Morro, Gruta Volks Clube, Toca do Falcão, Gruta Mogi, Toca Mata da Anta e Fenda do Barreiro). Esse fato pode indicar o uso de cavernas apenas como abrigo noturno no Distrito Federal (ver discussão sobre a importância desses abrigos em KunZ 1982). Contudo, isso contraria o observado no Alto Ribeira, onde $A$. caudifer utilizou freqüentemente cavernas como abrigo diurno, constituindo a terceira espécie de morcego em termos de abundância relativa nesse tipo de ambiente (Trajano 1985). CAMPANHã \& FOWLER (1993) encontraram esta espécie abrigando-se em duas pequenas cavernas da região de Corumbataí, onde formavam agrupamentos de cinco a 10 indivíduos. No leste do Peru, esta espécie também utilizou pequenas cavernas como abrigo diurno (Graham 1988). Segundo Trajano (1996), A. caudifer tem hábitos nômades e muda com freqüência de um abrigo para outro; essas mudanças podem ser conseqüência da disponibilidade local de alimento (flutuações na abundância de flores). No Alto Ribeira, onde essa espécie é comum, acredita-se que esteja substituindo G. soricina nas cavernas (TRAJANO 1985). Pelos comentários acima, podemos supor que $A$. caudifer utilize, como abrigo diurno, cavernas também na região do Distrito Federal; porém, não abrangidas pelo presente estudo.

Anoura caudifer foi capturada nos meses de abril, agosto, setembro, outubro, novembro e dezembro. Não temos dados sobre sua reprodução. No Vale do Ribeira, esta espécie parece reproduzir-se na estação chuvosa (TRAJANO 1985).

Platyrrhinus lineatus (E. Geoffroy, 1810)

Espécie frugívora capturada somente em sessões noturnas, enquanto adentrava seis cavidades naturais da região do Distrito Federal: Gruta Morro, Gruta 
Fenda II, Gruta Dois Irmãos, Gruta Agua Rasa, Toca da Gameleira e Gruta das Orquídeas. Nenhum indivíduo de $P$. lineatus foi observado abrigando-se em seu interior; porém, acreditamos que esta espécie deve utilizar cavernas também como abrigo diurno pois foram capturados exemplares em vários meses ao logo do ano (abril, maio, agosto, setembro, outubro e dezembro). Uma outra possibilidade seria o uso noturno de cavernas como local de ingestão de alimento, de modo semelhante ao observado para Artibeus fimbriatus nas cavernas do Alto Ribeira (ver TRAJANO 1985). Contudo, descartamos essa possiblidade pois nunca capturamos $P$. lineatus carregando frutos enquanto adentrava as cavernas do Distrito Federal e nem encontramos restos de frutos no chão das referidas cavernas. $\mathrm{O}$ fato de $P$. lineatus poder se abrigar em cavernas, onde formariam pequenas colônias, é conhecido na literatura (ver WILLIG \& HolLANDER 1987; TRAJANO 1995); porém, esta espécie parece preferir folhagem como abrigo diurno (NowAK 1991).

$\mathrm{O}$ uso de cavernas como abrigo diurno foi registrado somente em duas grutas de Goiás (Gruta Escaroba-GO 099 e Gruta Primavera-GO 025), situadas próximas ao Distrito Federal, não incluídas no presente estudo. Nessas grutas, grupos de quatro e de seis indivíduos foram observados pousados no teto do conduto junto a entrada das cavidades, à uma altura de quatro a cinco metros do solo. Os morcegos mantinham contato corporal entre si, formando cachos. $\mathrm{Na}$ Gruta Primavera, quatro fêmeas grávidas, foram capturadas em setembro. No nordeste do Brasil, WILLIG (1985) observou fêmeas grávidas desde o início da estação seca (julho) até o final da estação chuvosa (fevereiro/março). No Rio de Janeiro, PERACCHI \& ALBUQUERQUE (1971) capturaram fêmeas grávidas somente em dezembro, janeiro e março (estação chuvosa). Por outro lado, TADDEI (1976) encontrou fêmeas grávidas durante $o$ ano todo, com exceção apenas de abril. WILLIG (1983) sugere que machos adultos mantêm haréns de sete a 15 fêmeas. Abrigos contendo somente machos nunca foram encontrados pelo autor. Os indivíduos que compõem o harém mantêm contato corporal, quando em repouso no abrigo.

\section{Myotis nigricans (Schinz, 1821)}

No presente estudo, 18 exemplares desta espécie insetívora foram capturadas enquanto adentravam cinco cavidades naturais do Distrito Federal (Gruta Dança dos Vampiros, Gruta da Barriguda, Gruta Volks Clube, Gruta Kipreste e Fenda do Barreiro). Nunca observamos $M$. nigricans abrigando-se no seu interior; porém registramos essa espécie em diversos meses ao longo do ano (fevereiro, maio, junho, julho, agosto e outubro). Por esse motivo, suspeitamos que deve residir nessas cavernas. É possível que os agrupamentos se alojem em pequenas frestas nas paredes e teto das cavernas do Distrito Federal, não tendo sido percebidos por nós. O hábito de $M$. nigricans abrigar-se em frestas já foi descrito na literatura (ver KUNZ 1982; Trajano 1985, 1987). Em Trinidad e Tobago, GoodwIN \& GreEnHALl (1961) observaram esta espécie utilizando cavernas, ocos-de-árvore e paredes duplas de edificações, como abrigo diurno. No leste do Peru, M. nigricans utiliza grandes cavernas e construções (GraHAM 1988). Segundo TrAJANO (1995), esta espécie tem sido freqüentemente observada em cavernas brasileiras.

No Distrito Federal, fêmeas grávịdas de $M$. nigricans foram observadas somente em maio e outubro. Segundo WiLSON \& FInDLEY (1970), esta espécie 
apresenta um ciclo poliestro, com reprodução contínua ao longo do ano, cessando somente entre outubro e dezembro. No Panamá, a atividade reprodutiva iniciava-se em dezembro (período de máxima abundância de insetos), com um pico de nascimento de filhotes em fevereiro; há ainda um pico secundário de nascimento em abril-maio e um terceiro em agosto (EISENBERG 1989).

\section{Micronycteris minuta (Gervais, 1856)}

O único exemplar, macho, dessa rara espécie insetívora foi capturado na Toca do Falcão, enquanto adentrava a caverna. No leste do Peru, $M$. minuta foi encontrada somente em duas grandes cavernas, onde coabitou com nove espécies (GRAHAM 1988). Em Trinidad, pode abrigar-se em ocos-de-árvore e cavernas, geralmente em associação com outras espécies (GoODWIN \& GREENHALL 1961). Segundo WILSON (1979), seu período reprodutivo deve ocorrer na estação chuvosa. Na região do Distrito Federal, duas fêmeas grávidas foram capturadas em agosto, em duas localidades rurais (A. Bredt, não publicado). Não temos dados sobre sua biologia e pouco tem sido publicado na literatura.

\section{Eptesicus brasiliensis (Desmarest, 1819)}

No presente estudo, capturamos somente um indivíduo, macho, de E. brasiliensis na Gruta Morro em abril de 1993. O fato do único indivíduo desta espécie insetívora, relativamente comum em coleções, ter sido capturado somente enquanto adentrava a caverna sugere que a mesma não a utiliza como abrigo diurno. Além disso, exemplares de E. brasiliensis nunca foram observados no seu interior e nem coletados em seis outras visitas a mesma gruta.

\section{Conservação das Cavernas e dos Morcegos da Região do Distrito Federal}

Uma vez que cavernas são o principal tipo de abrigo utilizado por diversas espécies de morcegos, a preservação desses locais deveria ser um dos principais objetivos quando se pensa em conservação da quiropterofauna (ARITA 1996). A mineração, o uso recreativo das cavernas, o vandalismo, o desmatamento e o manejo de florestas tem contribuído para a redução do número e da diversidade de locais de abrigo para os morcegos, em diversas regiões do mundo (KUNZ 1982). Durante as duas últimas décadas, diversos esforços tem sido feitos para diminuir a perda de abrigos disponíveis, especialmente na Europa e na America do Norte, de modo a proteger os morcegos (KuNZ 1982). No Brasil, o interesse na preservação das espécies de morcegos e dos ambientes cavernícolas é ainda relativamente recente (ver AgUiaR \& TADDEI 1995; TRAJANO 1995; MARINHO-FILHO 1996; UIEDA \& PEDRO 1996). Medidas seguras para atingir esses objetivos ainda precisam ser discutidas e estabelecidas de modo a se evitar conflitos com as áreas interessadas no controle de morcegos hematófagos (D. rotundus), nos problemas relacionados à presença de morcegos em áreas urbanas e nos de saúde pública (ver BREDT et al. 1996).

No presente estudo, verificamos que quatro fatores tem prejudicado as cavernas estudadas na região do Distrito Federal. A visitação pública tem afetado $20 \%$ delas; a mineração de calcário para produção de cimento $10 \%$, a urbanização 
afeta $5 \%$ delas, e o desmatamento associado à visitação afeta uma das cavernas (5\%). Esses fatores têm levado à diminuição das populações cavernícolas e da diversidade de espécies dessas cavernas no Distrito Federal. O fator mais drástico foi a urbanização com loteamento da área ao redor da Gruta Volks Clube, que levou ao desaparecimento total da quiropterofauna, constatado em novembro de 1994. A localização peri-urbana dessa cavidade contribuiu para a rápida e crescente perturbação e conseqüentemente para o desaparecimento dos morcegos. Apesar dessa gruta ter abrigado uma baixa riqueza de espécies (quatro), a sua perda representou a redução de $25 \%$ dos abrigos de duas delas (C. auritus e $A$. geoffroyi). Para $L$. dekeyseri, única espécie de morcego endêmica do Cerrado (MARINHO-FILHO 1996), dois de seus três abrigos são afetados por visitação pública. Uma dessas grutas (Gruta Dois Irmãos) apresenta um fator de perturbação adicional (desmatamento) e a combinação desses fatores pode levar sua fauna rapidamente à extinção. Sugerimos que estudos ecológicos sobre $L$. dekeyseri sejam desenvolvidos visando sua proteção e de seu ambiente, pois, segundo MARINHO-FILHO (1996), a região do cerrado vem sofrendo um rápido e agressivo desenvolvimento econômico e demográfico.

Das cavernas estudadas, $60 \%$ não apresentaram nenhum fator de perturbação aparente e estão relativamente protegidas devido à sua pouca acessibilidade. Entre estas cavernas, a metade contêm uma riqueza de espécies relativamente alta (seis ou mais). Duas espécies consideradas como raras na região ( $P$. gymnonotus e $P$. stenops) estão aparentemente protegidas nessas cavernas.

Para ARITA (1993), um plano efetivo para a conservação dos morcegos cavernícolas mexicanos requer uma estratégia dupla: a proteção das cavernas com alta diversidade e altas populações multiespecíficas (maior que 1.000 indivíduos) e o manejo de morcegos cavernícolas de especial interesse (espécies frágeis, vulneráveis e endêmicas). Em relação a elaboração de um plano de conservação da quiropterofauna cavernícola da região do Distrito Federal, sugerimos que especial atenção seja dada as seguintes cavidades naturais: Gruta Morro, Gruta Fenda II, Gruta da Saúva, Gruta Dança dos Vampiros, Gruta Dois Irmãos, Gruta Água Rasa, Gruta da Barriguda e Toca da Gameleira. Essas cavernas abrigam uma alta riqueza de espécies de morcegos, duas espécies raras e uma endêmica do Cerrado. $\mathrm{O}$ fato de não termos dados sobre a densidade populacional dos animais nesses abrigos não diminui sua importância para conservação dos morcegos cavernicolas.

Um dos fatores de perturbação não avaliado no presente estudo foi o controle de populações de $D$. rotundus. As cavernas com grandes colônias desta espécie, como Gruta Morro, Gruta Boca do Lobo e Fenda do Barreiro possuem um considerável potencial de perturbação, pois a redução drástica ou eliminação total das colônias de $D$. rotundus podem trazer alterações na distribuição espacial das outras espécies, e nas condições topoclimáticas, certamente afetará diretamente os organismos dependentes do guano de morcegos hematófagos (TRAJANO 1995). 
W.A Pedro, pela uso de informações não publicadas; a João B. da Costa, Mauro L. Martins, Paulo H. de Oliveira, Elilia R.N. Rocha e Edgard D. Magalhães pelo valioso auxílio nos trabalhos de campo; à FAP-DF (190280/94) e FAPESP (94/2235-2) pelo financiamento de parte do trabalho, e a Fundação Nacional de Saúde pelo custeio de parte das viagens de W. Uieda a Brasilia.

\section{REFERÊNCIAS BIBLIOGRÁFICAS}

AGUiAR, L. \& V.A. TADDEI. 1995. Workshop sobre a conservação dos morcegos brasileiros. Chiroptera Neotropical 1 (2): 24-29.

Allen, G.M. 1939. Bats. New York, Dover, 368p.

Alonso-MeJí, A. \& R.A. Medellín. 1991. Micronycteris megalotis. Mammal. Species 376: 1-6.

Altringham, J.D. 1996. Bats, biology and behaviour. Oxford, Oxford Univ. Press, 262p.

Arata, A.A. \& J.B. Vaughan, 1970 Analyses of the relative abundance and reproductive activity of bats in southwestern Colombia. Caldasia 10 (50): 517-528.

ARITA, H.T. 1993. Conservation biology of the cave bats of Mexico. Jour. Mamm. 74 (3): 693-702.

1996. The conservation of cave-roosting bats in Yucatan, Mexico. Biol. Conserv. 76: 177-185.

ARITA, H.T. \& J.A. VARGAS. 1995. Natural history, interspecific association, and incidence of the cave bats of Yucatán, México. Southwest. Nat. 40 (1): 29-37.

BAteman, G.C. \& T.A. VAUGHAN. 1974. Nightly activities of mormoopid bats. Jour. Mammal. 55 (1): 45-65

BAUMgarten, J.E. \& E.M. VIEIRA. 1994. Reproductive seasonality and development of Anoura geoffroyi (Chiroptera: Phyllostomidae) in central Brazil. Mammalia 58 (3): 415-422.

BRASIL. 1990. Decreto nº 99.556 de 01 de outubro de 1990. Dispõe sobre a proteção das cavidades subterrâneas no território nacional e dá outras providências. Diário Oficial da República Federativa do Brasil, Brasília, v. 128, n. 190, p. 18.836, 20 de outubro de 1990.

Bredt, A.; F.A.A. Araujo; J. Caetano-Junior; M.G.R. Rodrigues; M. Yoshizawa; M.M.S. Silva; N.M.S. Harmani; P.N.T. Massunaga; S.P. BurER; V.A.R PORTO \& W. UIEDA. 1996. Morcegos de áreas urbanas e rurais: manual de manejo e controle. Brasília, Ministério da Saúde, Fundação Nacional de Saúde, 117p.

BREDT, A. \& W. UiEDA. 1996. Bats from urban and rural environments of the Distrito Federal, Mid-western Brazil. Chiroptera Neotropical 2 (2): 54-57.

CAmargo, L. \& J.R. TAMSiTT. 1990. Second occurrence of the smoky bat (Furipterus horrens) in Colombia. Mammalia 54 (1): 157-158.

CAMPANHÃ, R.A. \& H.G. FowLER. 1993. Roosting assemblages of bats in Arenitic caves in remnant fragments of Atlantic forest in Southeastern Brazil. Biotropica 25 (3): 362-365.

1995. Movement patterns and roosts of the vampire bat Desmodus 
rotundus in the interior of São Paulo State. Naturalia, São Paulo, 20: 191-194. CARdoso, M. 1995. Prey-type of the vampire bat Desmodus rotundus from Mid-Western Brazil, revealed by tests of precipitin on stomach blood meal. Chiroptera Neotropical 1 (2): 31-32.

Ceballos-GonZÁlez, G. \& C. Galindo-Leal. 1984. Mamíferos silvestres de la

Cuenca de México. México, Limusa, 299p.

Cloutier, D. \& D.W. Thomas. 1992. Carollia perspicillata. Mammal. Species 417: $1-9$.

Codeplan. 1984. Atlas do Distrito Federal. Brasília, Companhia de

Desenvolvimento do Planalto, $79 \mathrm{p}$.

Colmbra JR., C.E.A.; M.M. Borges; D.Q. GuerRA \& D.A. Mello. 1982. Contribuição à zoogeografia e ecologia de morcegos em regiões de cerrado do Brasil Central. Bol. Tec. Rev. Brasil Florestal, IBDF, 7: 34-38.

DNPM. 1981. Geologia e inventário dos recursos minerais da região central do Estado de Goiás - Projeto Brasília. Brasília, 148p.

EISENBERG, J.F. 1989. Mammals of the Neotropics, the northern Neotropics:

Panama, Colombia, Venezuela, Guyana, Suriname, French Guiana. Chicago, Chicago Univ. Press, Vol. 1, X+449p.

EITEN, E. 1990. Vegetação, p.9-65. In: M. Novaes-Pinto (Ed.). Cerrado: caracterização, ocupação e perspectivas. Brasília, Ed. Unb, $681 \mathrm{p}$.

FEnTON, M.B. \& T.H. KUNZ. 1977. Movements and behavior, p. 351-364. In: R.J. BAKER; J.K. JONES JR. \& D.C. CARTER (Eds). Biology of bats of the New World family Phyllostomatidae, Part II. Spec. Publs. Mus. Texas Tech. Univ. 13: $1-364$.

GARDNER, A.L. 1977. Feeding habits, p.293-350. In: R.J. BAKER; J.K. JONES JR. \&

D.C. CARTER (Eds). Biology of bats of the New World family Phyllostomatidae,

Part II. Spec. Publs. Mus. Texas Tech. Univ. 13: 1-364.

Goodwin, G.G. \& A.M. GreenHALL. 1961. A review of the bats of Trinidad and Tobago. Bull. Amer. Mus. Nat. Hist. 122: 187-302.

GRAHAM, G.L. 1988. Interspecific associations among Peruvian bats at diurnal roosts and roost sites. Jour. Mamm. 69 (4): $711-720$.

GreENHALL, A.M. 1988. Feeding behavior, p.111-131. In: A.M. GREENHALL \& U.

SCHMIDT (Eds). Natural history of vampire bats. Florida, CRC Press, 246p. Greenhall, A.M.; G. Joermann \& U. SchmidT. 1983. Desmodus rotundus.

Mammal. Species 202: 1-6.

Greenhall, A.M.; U. Schmidt \& G. Joermann. 1984. Diphylla ecaudata.

Mammal. Species 227: 1-3.

Herd, R.M. 1983. Pteronotus parnellii. Mammal. Species 209: 1-5. JEPSEN, G.L. 1970. Bat origins and evolution, p.1-64. In: W.A. WiMSATT (Ed.).

Biology of bats. New York, Academic Press, Vol. 1, XII+406p.

KARMANN, I.L.E. 1979. Distribuição das rochas carbonáticas e províncias espeleológicas do Brasil. Espeleotema 13: 105-167.

KunZ, T.H. 1982. Roosting ecology of bats, p.1-55. In: T.H. KunZ (Ed.). Ecology of bats. New York, Plenum Press, XVIII+425p.

LASSIEUR, S. \& D.E. WILSON. 1989. Lonchorhina aurita. Mammal. Species 347: $1-4$. 
LAVAL, R.K. 1977. Notes on some Costa Rican bats. Brenesia 10/11: 77-83.

MARINHO-FILHO, J.S. 1996. The Brazilian cerrado bat fauna and its conservation. Chiroptera neotropical 2 (1): 37-39.

MCCRACKEN, G.F. \& J.W. BRADBURY. 1981. Social organization and kinship in the polygonous bat Phyllostomus hastatus. Behav. Ecol. Sociobiol. 8: 11-34.

MEdellín, R.A. 1989. Chrotopterus auritus. Mammal. Species 343: 1-5.

NoWAK, R.M. 1991. Walker's mammals of the world. Baltimore, John Hopkins Univ. Press, $5^{\mathrm{a}}$ Ed., 1629p.

Ortega, J. \& H.T. ARita. 1997. Mimon bennettii. Mammal. Species 549: 1-4.

PERACCHI, A.L. \& S.T. AlBuQUERQUe. 1971. Lista provisória dos quirópteros dos estados do Rio de Janeiro e Guanabara, Brasil (Mammalia, Chiroptera). Rev. Brasil. Biol. 31: 405-413.

PICCININI, R.S. \& C.A.C. AQUINO. 1979. Aplicação experimental do anticoagulante Diphenadiona (2-difenilacetil-1,3, indandiona) no controle ao vampiro, Diphylla ecaudata Spix, 1823, no Estado do Rio de Janeiro, Brasil. Bol. Def. Sanit. Anim. 13 (1-4): 126-131.

RANSOME, R.D. 1990. The natural history of hibernating bats. London, Chistopher Helm, 235p.

REDForD, K.H. \& J.F. EISENBERG. 1992. Mammals of the neotropics, The Southern cone, Chile, Argentina, Uruguay, Paraguay. Chicago, Univ. Chicago Press, Vol. 2, IX+430p.

RoDrigues, M.G.R.; A. BREDT \& W. UIEDA. 1994. Arborização de Brasília, Distrito Federal, e possíveis fontes de alimento para morcegos fitófagos. An. Cong. Brasil. Arbor. Urb. 2: 311-326.

SAZIMA, I. 1978. Vertebrates as food items of the wooly false vampire, Chrotopterus auritus. Jour. Mamm. 59 (3): 617-618.

SCHMIDT, C. 1988. Reproduction, p. 99-109. In: A.M. GREENHALL \& U. SCHMIDT (Eds). Natural history of vampire bats. Florida, CRC Press, 246p.

Silva, M.M.S.; N.M.S. HaRMani; E.F.B. GonçAlves \& W. Uieda. 1996. Bats from the metropolitan region of São Paulo, Southeastern Brazil. Chiroptera Neotropical 2 (1): 39-41.

TAdDEI, V.A. 1976. The reproduction of some Phyllostomidae (Chiroptera) from the Northwestern region of the State of São Paulo. Bol. Zool. Univ. São. Paulo 1: 313-330.

1983. Morcegos. Algumas considerações sistemáticas e biológicas. Bol. Téc. Cati, Campinas, 172: 1-31.

TAdDEI, V.A.; L.D. VizotTo \& I. Sazima. 1983. Uma nova espécie de Lonchophylla do Brasil e chave para identificação das espécies do gênero (Chiroptera, Phyllostomidae). Ciência e Cultura 35 (5): 625-629.

TRAJANO, E. 1985. Ecologia de populações de morcegos cavernícolas em uma região cárstica do Sudeste do Brasil. Revta bras. Zool. 2 (5): 255-320.

- 1987. Fauna cavernícola brasileira: composição e caracterização preliminar. Revta bras. Zool. 3 (8): 533-561.

1995. Protecting caves for the bats or bats for the caves? Chiroptera Neotropical 1 (2): 19-22.

. 1996. Movements of cave bats in Southeastern Brazil, with emphasis on 
the population ecology of the common vampire bat, Desmodus rotundus (Chiroptera). Biotropica 28 (1): 121-129.

Trajano, E. \& J.R.A. Moreira. 1991. Estudo da fauna de cavernas da província espeleológica arenítica Altamira-Itaituba, Pará. Rev. Brasil. Biol. 51 (1): 13-29. UIEDA, W. 1996. Biologia e dinâmica populacional de morcegos hematófagos no Brasil. Anais II Curso de Atualização em Raiva dos Herbívoros, Curitiba, 2: 63-87.

UiEDA, W.; I. SAZIMA \& A. STORTI FiLho. 1980. Aspectos da biologia do morcego Furipterus horrens (Mammalia, Chiroptera, Furipteridae). Rev. Brasil. Biol. 40 (1):59-66.

UiedA, W. \& W.A. Pedro. 1996. Chiroptera in the XXI Brazilian Zoology Congress. Chiroptera Neotropical 2 (1): 41-42.

VAugahn, T.A. \& R.P. VAughan. 1987. Parental behavior in the african yellow-winged bat (Lavia frons). Jour. Mamm. 68 (2): 217-223.

WILKINSON, G.S. 1988. Social organization and behavior, p.85-97. In: A.M. GREENHALL \& U. SCHMIDT (Eds). Natural history of vampire bats. Florida, CRC Press, 246p.

Willig, M.R. 1983. Composition, microgeographic variation, and sexual dimorphism in caatinga and cerrado bat communities from northeast Brazil. Bull. Carnegie Mus. Nat. Hist. 23: 1-131.

-1985. Reproductive patterns of bats from caatingas and cerrado biomes in northeast Brazil. Jour. Mamm. 66 (4): 668-681.

Willig, M.R. \& R.R. Hollander. 1987. Vampyrops lineatus. Mammal. Species 275: $1-4$.

WILSON, D.E. 1979. Reproductive patterns, p. 317-378. In: R.J. BAKER; J.K. JONES JR. \& D.C. CARTER (Eds). Biology of bats of the New World family Phyllostomatidae. Part III. Spec. Publ. Mus. Texas Tech. Univ. 16: 1-441.

Wilson, D.E. \& J.S. FINDLEY. 1970. Reproductive cycle of a neotropical insectivorous bat, Myotis nigricans. Nature 225: 1155.

Recebido em 27.II.1998; aceito em 19.VII.1999. 